\title{
On Polarimetric Radar Signatures of Deep Convection for Model Evaluation: Columns of Specific Differential Phase Observed during MC3E*
}

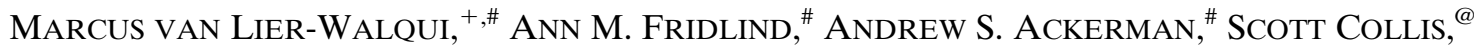 \\ JONATHAN HELMUS, ${ }^{@}$ DONALD R. MACGORMAN, ${ }^{\&, * *}$ KIRK NORTH, ${ }^{++}$ \\ PAVlOS KOLliAs, ${ }^{++}$AND DEREK J. POSSELT ${ }^{\# \#}$ \\ ${ }^{+}$CCSR, Columbia University, New York, New York \\ \# NASA Goddard Institute for Space Studies, New York, New York \\ ${ }^{@}$ Environmental Sciences Division, Argonne National Laboratory, Argonne, Illinois \\ \& NOAA/National Severe Storms Laboratory, Norman, Oklahoma \\ ** Cooperative Institute for Mesoscale Meteorological Studies, Norman, Oklahoma \\ ${ }^{++}$McGill University, Montreal, Quebec, Canada \\ \#\# University of Michigan, Ann Arbor, Michigan
}

(Manuscript received 17 March 2015, in final form 9 October 2015)

\begin{abstract}
The representation of deep convection in general circulation models is in part informed by cloud-resolving models (CRMs) that function at higher spatial and temporal resolution; however, recent studies have shown that CRMs often fail at capturing the details of deep convection updrafts. With the goal of providing constraint on CRM simulation of deep convection updrafts, ground-based remote sensing observations are analyzed and statistically correlated for four deep convection events observed during the Midlatitude Continental Convective Clouds Experiment (MC3E). Since positive values of specific differential phase $K_{\mathrm{DP}}$ observed above the melting level are associated with deep convection updraft cells, so-called $K_{\mathrm{DP}}$ columns are analyzed using two scanning polarimetric radars in Oklahoma: the National Weather Service Vance WSR88D (KVNX) and the Department of Energy C-band Scanning Atmospheric Radiation Measurement (ARM) Precipitation Radar (C-SAPR). KVNX and C-SAPR $K_{\mathrm{DP}}$ volumes and columns are then statistically correlated with vertical winds retrieved via multi-Doppler wind analysis, lightning flash activity derived from the Oklahoma Lightning Mapping Array, and KVNX differential reflectivity $Z_{\mathrm{DR}}$. Results indicate strong correlations of $K_{\mathrm{DP}}$ volume above the melting level with updraft mass flux, lightning flash activity, and intense rainfall. Analysis of $K_{\mathrm{DP}}$ columns reveals signatures of changing updraft properties from one storm event to another as well as during event evolution. Comparison of $Z_{\mathrm{DR}}$ to $K_{\mathrm{DP}}$ shows commonalities in information content of each, as well as potential problems with $Z_{\mathrm{DR}}$ associated with observational artifacts.
\end{abstract}

\section{Introduction}

\section{a. Motivation}

This study lays the groundwork for observational evaluation of cloud-resolving model simulations by quantifying statistical properties of objectively identified

* Supplemental information related to this paper is available at the Journals Online website: http://dx.doi.org/10.1175/MWR-D15-0100.s1.

Corresponding author address: Marcus van Lier-Walqui, CCSR, Columbia University, 2880 Broadway, New York, NY 10027.

E-mail: marcus.vanlier-walqui@nasa.gov radar observables, namely specific differential phase $K_{\mathrm{DP}}$, and establishing their correlation with collocated retrieval of vertical winds, as well as precipitation rate, and lightning flash activity, which are also closely related to updraft properties. This will allow for future work to test approaches for comparing high-resolution simulations and observations that rely primarily on the strengths identified in the analysis of $K_{\mathrm{DP}}$ presented herein.

The microphysical properties of mature deep convection updrafts remain poorly quantified, at least in part because of sparse in situ measurements available from aircraft campaigns, which provide the only direct means of measuring hydrometeor mixing ratio, morphology, size distribution, and phase within strong updrafts (Heymsfield et al. 2002; Stith et al. 2002, 2004; 
Anderson et al. 2005; Stith et al. 2006; Lawson et al. 2010). A glaring result is the lack of observational data adequate to quantitatively constrain order-of-magnitude differences in condensate mixing ratios commonly predicted by cloud-resolving simulations of deep convection systems using differing microphysics schemes, where interaction of dynamics and microphysics schemes likely contribute to differences (Varble et al. 2011; Zhu et al. 2012; Collis et al. 2013; Varble et al. 2014a,b). This dearth of in situ measurements is furthermore unlikely to be quickly remedied owing to the difficulty of obtaining robust statistics by aircraft over sparsely distributed and rapidly evolving features. With research-grade simulations poorly constrained, it is extraordinarily difficult to robustly establish higher-order differences in updraft properties, such as those induced by changes in aerosol fields [see reviews by Levin and Cotton (2008) and Tao et al. (2012)], which have been hypothesized to influence climate via their influence on deep convection.

Instead of directly constraining hydrometeor concentrations, observations can be used to inform the microphysical processes present in deep convective updrafts. Perhaps the most promising sources of data now available for that task are scanning polarimetric radars, including those operated by the U.S. National Weather Service and the Department of Energy's Atmospheric Radiation Measurement (ARM) program (Ackerman and Stokes 2003; Mather and Voyles 2013). Such radars offer wide-domain and continuous coverage in time, but likely require an analysis approach that is suited to their strengths, which do not currently include robust retrieval of condensate mixing ratios within updrafts, for instance, but may include signatures associated with the microphysical processes of deep convection.

Within the high-resolution and global modeling community, radar reflectivity (typically horizontally polarized radar reflectivity $Z_{\mathrm{HH}}$ ) has been effectively used, for example, to define convective and stratiform regions using the Steiner and Smith (1998) algorithm (e.g., Caniaux et al. 1995; Gray 2000; Lang et al. 2003; Mechem et al. 2006; Braun et al. 2010; Fridlind et al. 2012; Zeng et al. 2013; Mrowiec et al. 2015). Additionally, contoured frequency with altitude (CFAD) plots of reflectivity are used to evaluate differences in modeled and observed storm microphysics and dynamics (Lang et al. 2003; Blossey et al. 2007; Matsui et al. 2009; Shi et al. 2010; Lang et al. 2011; Tao et al. 2014; Matsui et al. 2015). These methods have proven valuable in illustrating gross differences between modeled and observed storm characteristics; however, they do not provide specific information on, for example, the prevalence, spatial distribution, and strength of deep convective updrafts. There would be much potential value in an observational metric of deep convective storms that is capable of providing these data, providing that it could be effectively compared to analogous metrics calculated from numerical model simulations. The current work provides background for the use of columns of $K_{\mathrm{DP}}$ as an observational constraint on modeled deep convective updrafts.

This study focuses on polarimetric precipitation radar observations owing to their ability to provide unique information about hydrometeors involved in updraft microphysical processes (Bringi et al. 1996; Hubbert et al. 1998; Loney et al. 2002; Kumjian et al. 2014a). In particular, it focuses on the presence of elevated positive values of $K_{\mathrm{DP}}$ above the environmental $0^{\circ} \mathrm{C}$ isotherm, which strongly suggests significant quantities of lofted liquid rain and/or water-coated ice, and thus, the presence of deep convection updrafts (Bringi et al. 1996; Hubbert et al. 1998; Loney et al. 2002). For a review of $K_{\mathrm{DP}}$ and other polarimetric variables, in the interest of space we refer the reader elsewhere (Doviak and Zrnić 1993; Zrnić and Ryzhkov 1999; Bringi and Chandrasekar 2001; Kumjian 2013).

Because the ultimate goal is to use these radar observations to constrain model simulations, we require that these observations be robust, both from the perspective of observational uncertainties, as well as from the perspective of forward modeling these observations. In both regards, the choice of $K_{\mathrm{DP}}$ is attractive. With regard to observational artifacts and uncertainty, $K_{\mathrm{DP}}$ is arguably more robust than $Z_{\mathrm{DR}}$ as an observational indicator of the presence of rain or liquid-coated ice particles above the melting level throughout the life cycle of a convection cell. For example, results from Kumjian et al. (2014a) suggest that as hail mass becomes significant from the perspective of reflectivity, $Z_{\mathrm{DR}}$ is depressed despite the continued presence of both a convective updraft and rain above the melting level. In such cases, $K_{\mathrm{DP}}$ above the melting level is likely to better track the full life cycle of a convection updraft. Additionally, $K_{\mathrm{DP}}$-related rain rate statistics have been shown to have good fidelity, even for radar frequencies susceptible to attenuation errors (Giangrande et al. 2014). Differential reflectivity $Z_{\mathrm{DR}}$ is possibly preferable to $K_{\mathrm{DP}}$ as a signal of the initial stages of a deep convective updraft because it does not require significant concentrations of oblate hydrometeors and is, thus, better able to characterize the initial evolution of an updraft where liquid hydrometeors may be present above the $0^{\circ} \mathrm{C}$ isotherm in low concentrations.

With regards to observational uncertainties, $Z_{\mathrm{DR}}$ is sensitive to both radar calibration errors, as well as differential attenuation, which is caused by propagation of the signal through oriented hydrometeors (Aydin et al. 
1989; Bringi and Chandrasekar 2001). Whereas $K_{\mathrm{DP}}$ is insensitive to both calibration and attenuation effects, although estimation of $K_{\mathrm{DP}}$ becomes complicated when backscatter differential phase is significant, as it is for particles that are large with respect to the radar wavelength (Aydin and Giridhar 1992; Carey et al. 2000; Giangrande et al. 2013), and $K_{\mathrm{DP}}$ may also be susceptible to cross-coupling effects (Hubbert et al. 2014).

For identification of deep updrafts, $K_{\mathrm{DP}}$ is preferred to radar reflectivity for a number of reasons. In deep convection, high reflectivity may indicate high concentrations of rain and ice-phase hydrometeors such as hail, graupel, and mixed-phase hydrometeors. By comparison, elevated positive values of $K_{\mathrm{DP}}$ are generally related to liquid rain or liquid-coated hydrometeors, which produce positive $K_{\mathrm{DP}}$ owing to their oblateness. Considering only rain, radar reflectivity, under the Rayleigh approximation, is proportional to the sixth moment of a drop size distribution. For the purposes of forward modeling observations, this results in strong and nonlinear sensitivity to assumptions in the modeled drop size distribution. By contrast, $K_{\mathrm{DP}}$ is approximately related to the fourth-fifth moment of the raindrop size distribution and is closely related to rain rate (Sachidananda and Zrnić 1986; Ryzhkov and Zrnić 1996; Zrnić and Ryzhkov 1999; Cifelli and Chandrasekar 2010). This last point relates to the robustness of forward simulation of $K_{\mathrm{DP}}$ from model results. In the current study, it is hypothesized that use of $K_{\mathrm{DP}}$ instead of $Z_{\mathrm{DR}}$ will reduce forward modeling uncertainties related to raindrop size distribution assumptions because $K_{\mathrm{DP}}$ is less sensitive to variations in assumptions of the rain drop size distribution than either reflectivity or $Z_{\mathrm{DR}}$.

The purpose of this study is to investigate the characteristics of $K_{\mathrm{DP}}$ as an observational signal of deep convective updrafts, in order to motivate its use as a constraint on numerical simulations. The focus is not on conclusively diagnosing the microphysical processes that produce $K_{\mathrm{DP}}$ columns, nor is it to use $K_{\mathrm{DP}}$ to study the dynamics of deep convection. Instead, $K_{\mathrm{DP}}$ columns observed in four midlatitude deep convection storm systems are analyzed to answer the following questions: 1) How does the signal of deep convection observed in the depth and volume of $K_{\mathrm{DP}}$ columns correlate with other metrics such as multi-Doppler wind retrievals and electrical storm activity? 2) How do the relationships between $K_{\mathrm{DP}}$ columns and other metrics of deep convection vary from storm to storm and within evolving storms systems during their life cycles? Addressing these issues will improve understanding of how $K_{\mathrm{DP}}$ columns, and more generally, positive $K_{\mathrm{DP}}$ above the melting level, characterize deep convective storm systems and their life cycles to aid forecasters and provide information needed to use $K_{\mathrm{DP}}$ to evaluate numerical models.

\section{b. Background}

Two prominent examples of analysis and interpretation of $K_{\mathrm{DP}}$ columns can be found in Hubbert et al. (1998) and Loney et al. (2002). Hubbert et al. (1998) documented S-band observations of a supercell observed by the CSU-CHILL radar in Colorado and analyzed $Z_{\mathrm{DR}}$, linear depolarization ratio (LDR), copolar correlation ratio $\left(\rho_{\mathrm{HV}}\right)$, and $K_{\mathrm{DP}}$ signatures. The authors interpret the $K_{\mathrm{DP}}$ column as a signal of small drops $(1-2 \mathrm{~mm})$ shed by wet hailstones by virtue of its location on the fringe of the identified updraft. Loney et al. (2002) present S-band polarimetric radar observations of an Oklahoma supercell collocated with in situ data collected from an aircraft. The aircraft sampled particle sizes along a path above the melting level through a region associated with roughly maximal $K_{\mathrm{DP}}$ values evident in CAPPI and vertical sections. Their results indicated radar observed elevated positive $K_{\mathrm{DP}}$ roughly collocated with the storm updraft, compared with $K_{\mathrm{DP}}$ forward simulated from in situ data, which showed peaks on either side of the updraft. Recently, Homeyer and Kumjian (2015) performed a composite analysis of polarimetric radar observations of organized, cellular, and supercellular deep convection across the Great Plains. This study showed the prevalence and consistency of $K_{\mathrm{DP}}$ and $Z_{\mathrm{DR}}$ columns in regions associated with convection that overshoots the altitude of the extratropical tropopause.

Electrical activity of storms has long been used as a signal of continental deep convection, to the extent that the word "thunderstorm" is used to describe such weather. It has been long understood that a dominant mechanism in separation of charge in thunderstorms is rebounding ice-ice collisions occurring between particles such as graupel and pristine ice in the presence of supercooled cloud water (Reynolds et al. 1957; Takahashi 1978; Jayaratne et al. 1983; Pereyra et al. 2000). Graupel is produced in regions where riming growth is dominant-in other words, regions of deep convection updrafts. Studies-for example, Deierling and Petersen (2008) — have confirmed a strong link between updraft volume and total flash rate in storm systems, with Wiens et al. (2005) stressing the importance of using flash density, rather than raw VHF source density, as a measure of lightning activity.

The role of mixed-phase microphysics in the separation of charge suggests that polarimetric variables such as $K_{\mathrm{DP}}$ and $Z_{\mathrm{DR}}$ observed above the melting layer may be linked to lightning activity. Multiple studies have confirmed and elaborated on the relationship between 
lightning activity and multi-Doppler radar-derived updrafts (Lang and Rutledge 2002; Tessendorf et al. 2007b,a; Deierling and Petersen 2008; Calhoun et al. 2013) and several have investigated the relationships between polarimetric variables and electrical activity in deep convection storms (Carey and Rutledge 1998; Tessendorf et al. 2005; Wiens et al. 2005; Bruning et al. 2007; Lund et al. 2009; Payne et al. 2010; Griffin et al. 2014).

\section{Data and methodology}

\section{a. Data}

\section{1) KVNX S-BAND POLARIMETRIC RADAR}

S-band polarimetric radar data was obtained from the National Weather Service WSR-88D (NEXRAD) Vance Oklahoma site (KVNX). This radar simultaneously transmits and receives electromagnetic waves with horizontal and vertical polarizations (STAR), meaning that measurements of cross-polarization variables such as LDR and cross-polar correlation coefficient $\rho_{\mathrm{xh}}$ are not possible using this radar. Level-II data from the National Climatic Data Center provide the variables horizontal reflectivity $Z_{\mathrm{HH}}$, differential reflectivity $Z_{\mathrm{DR}}$, differential phase $\Psi_{\mathrm{DP}}$, copolar correlation coefficient $\rho_{\mathrm{HV}}$, and radial velocity. The radar operated in volume coverage patterns (VCP) 11, 212, 12, and 212 for the 4 days, respectively; all modes featured 14 elevation scans performed in approximately $5 \mathrm{~min}$. At the time of the Midlatitude Continental Convective Clouds Experiment (MC3E), KVNX had an angular resolution of $1^{\circ}$ for all elevations angles (lower angles had improved $0.5^{\circ}$ resolution) and $250-\mathrm{m}-$ range resolution.

Differential phase $K_{\mathrm{DP}}$ is obtained from NEXRAD Level-II differential phase data $\Psi_{\mathrm{DP}}$ using the Giangrande et al. (2013) algorithm as implemented in the Python ARM Radar Toolkit (Py-ART) (Heistermann et al. 2015). This algorithm assumes a monotonic increase in $\Psi_{\mathrm{DP}}$ and is, thus, inappropriate for regions where negative $K_{\mathrm{DP}}$ is expected (such as in electrified ice fields or in the presence of conical graupel). Conversely, this algorithm is well suited to using $K_{\mathrm{DP}}$ to identify the presence of rain or liquid-coated hydrometeors lofted above the melting layer by strong convection updrafts-conditions where negative $K_{\mathrm{DP}}$ is not expected. Processing to retrieve $\Phi_{\mathrm{DP}}$ and $K_{\mathrm{DP}}$ requires filtering that reduces range resolution to approximately $1 \mathrm{~km}$ for $K_{\mathrm{DP}}$.

NEXRAD radar data, including the derived $K_{\mathrm{DP}}$ fields, are gridded using Py-ART gridding routines on a Cartesian grid with 1-km horizontal and 500-m vertical resolution. Care was taken in selecting the appropriate gridding algorithm to capture relevant detail while suppressing artifacts; we chose an inverse-distance weighted algorithm using a Barnes (1964)-like weighting function as in Collis et al. (2010) and Trapp and Doswell (2000). It should be noted that, at the time of MC3E, KVNX was the only operational NEXRAD radar in the region that was polarimetric. Future studies of large storm systems such as those observed during MC3E will no doubt benefit from enhanced spatial coverage of polarimetric NEXRAD radars.

\section{2) C-SAPR C-BAND POLARIMETRIC RADAR}

The Department of Energy (DOE) Atmospheric Radiation Measurement C-band ARM Scanning Precipitation Radar (C-SAPR) is a polarimetric $5-\mathrm{cm}$ wavelength radar that was located near the ARM Southern Great Plains (SGP) site at Lamont, Oklahoma, during this study. Like KVNX, it was run in STAR mode. The C-SAPR radar has approximately the same beamwidth as KVNX (approximately $1^{\circ}$ ) but much improved range resolution ( $90 \mathrm{~m}$ versus $250 \mathrm{~m}$ for $\mathrm{KVNX}$ ); $K_{\mathrm{DP}}$ range resolution for C-SAPR is approximately $250 \mathrm{~m}$ owing to filtering in the phase processing algorithm.

Data were analyzed on a Cartesian grid with 1-km horizontal and 500-m vertical resolution. Data were processed to derive $K_{\mathrm{DP}}$ from $\Psi_{\mathrm{DP}}$, again using the Giangrande et al. (2013) algorithm. Differential reflectivity $Z_{\mathrm{DR}}$ suffered from problems associated with differential attenuation from heavy precipitation observed on all days, compounded by the sensitivity of C-band radar measurements to such effects, and $Z_{\mathrm{DR}}$ from C-SAPR was therefore not used in this study. Additionally, a polarimetric rainfall estimation based on specific attenuation was used to derive rain rates from C-SAPR polarimetric radar variables (Ryzhkov et al. 2014; Giangrande et al. 2014). Giangrande et al. (2014) analyzed these data and compared them with estimates from X-band polarimetric radars as well as rain gauges; C-SAPR rain rates were shown to be in good agreement with rain gauges. Here we analyze rain rates above the 40 and $90 \mathrm{~mm} \mathrm{~h}^{-1}$ thresholds to illustrate convective and particularly intense rain rates, respectively.

\section{3) Multi-DopPler Wind ReTrieval}

The network of scanning precipitation Doppler radars at the ARM SGP site provides the capability to view the atmosphere from multiple different angles in under approximately $7 \mathrm{~min}$. During MC3E, the coordination of this network was of highest priority at times when significant convection events were imminent or occurring. We briefly describe the multi-Doppler wind retrieval method here. For a full description of the method, see North (2016). Fundamentally, the radial velocity observations from this network are ingested 


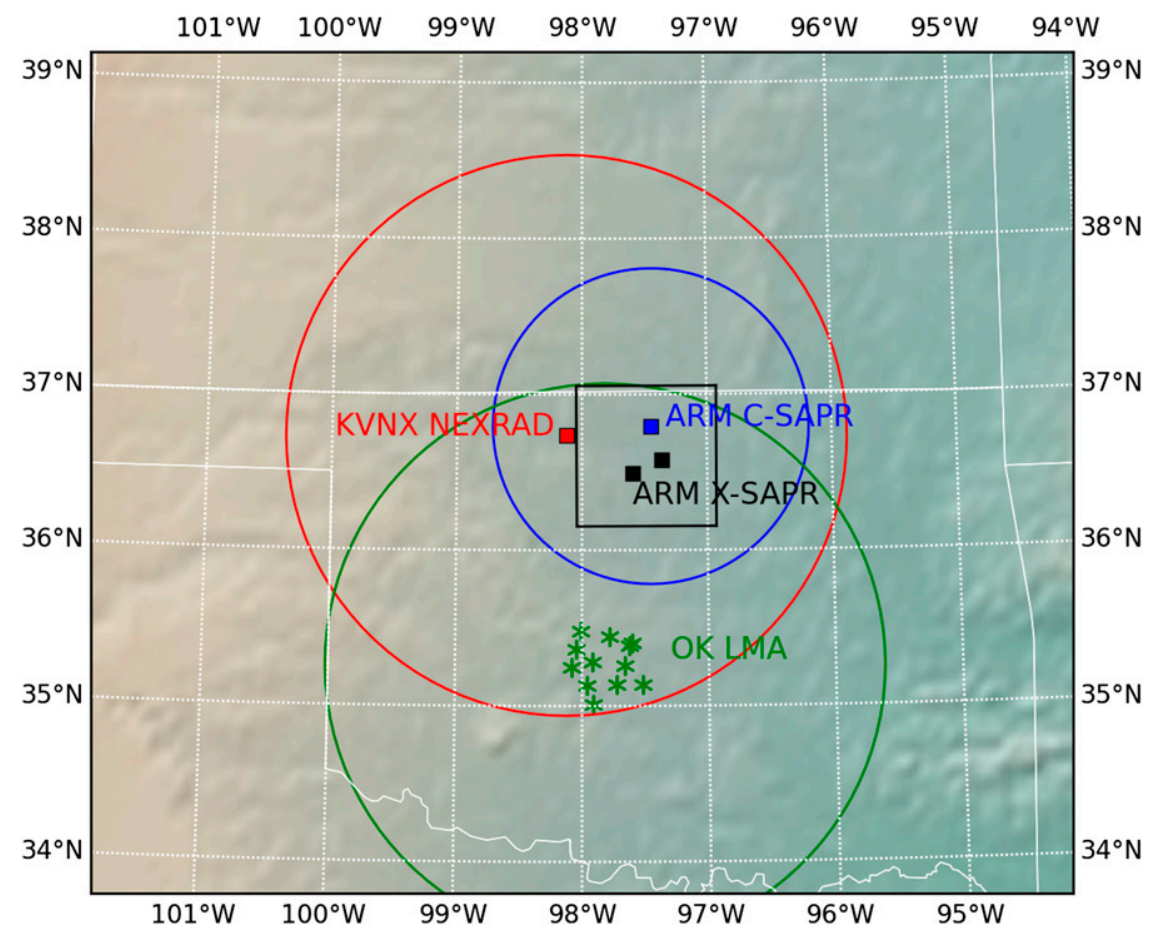

FIG. 1. Map of KVNX radar location with 200-km-range ring (red square and ring), C-SAPR radar location with 112-km-range ring (blue square and ring), LMA antennae locations and 200-km-range ring (green asterisks and ring), and domain of multi-Doppler wind retrieval (black box) with location of X-SAPR radars (black squares).

into a three-dimensional variational (3D-VAR) algorithm that minimizes a cost function defined as the sum of multiple independent constraints: radar Doppler radial velocity, mass continuity, a background field, and smoothness. Mass continuity in this case is the anelastic approximation for moist convection and is a required constraint owing to inadequate sampling of vertical air motion by scanning Doppler radars. The background field provides a physical solution in data-sparse regions, and the smoothness constraint is designed to reduce retrieval artifacts and extend properly constrained regions into poorly constrained regions. These four constraints are common in multi-Doppler wind retrieval literature. The analysis domain for these wind retrievals covers $100 \times 100 \mathrm{~km}^{2}$ around the SGP Central Facility and extends up to $10-\mathrm{km}$ altitude, with a horizontal resolution of $500 \mathrm{~m}$ and a vertical resolution of $250 \mathrm{~m}$. The radars used included the C-SAPR radar as well as two X-band (3-cm wavelength) ARM Scanning Precipitation Radars (X-SAPR) located near the central facility; the locations of these radars are shown in Fig. 1.

\section{4) OKLahoma Lightning Mapping Array}

The Oklahoma Lightning Mapping Array (LMA) is a time-of-arrival-based lightning mapping system that utilizes an array of very-high-frequency (VHF) antennas to provide a four-dimensional map of lightning activity in thunderstorms (MacGorman et al. 2008; Thomas et al. 2004). Vertical accuracy is limited at distances further than $100 \mathrm{~km}$ from the LMA and horizontal accuracy becomes limited at distances beyond $200 \mathrm{~km}$ from the LMA. For a given lightning strike, the LMA may detect between tens and thousands of VHF sources. As stated in section $1 \mathrm{~b}$, results from Wiens et al. (2005) suggest that better correlation is found between convection storm statistics (such as updrafts) and flashes rather than VHF sources. Clustering of VHF source into flashes was performed as suggested by MacGorman et al. (2008), with thresholds of $3 \mathrm{~km}$ and $0.25 \mathrm{~s}$ set for inclusion of a VHF source into a flash and a minimum of $10 \mathrm{VHF}$ sources required per flash. Data shown here represent the time and location of the first VHF source within a given flash. Collocated radar analysis is performed on data gridded from the Vance Oklahoma WSR-88D.

\section{5) $K_{\text {DP }}$ COLUMN ANALYSIS}

Specific differential phase $K_{\mathrm{DP}}$ columns were objectively identified from gridded C-SAPR and KVNX data. Gridded $K_{\mathrm{DP}}$ fields were integrated vertically within a 2-km slab above the melting level and smoothed using a 
TABLE 1. Summary of days considered in this study.

\begin{tabular}{|c|c|c|c|c|}
\hline Day & $\begin{array}{l}\text { Times analyzed } \\
\text { (UTC) }\end{array}$ & $\begin{array}{c}\text { Melting } \\
\text { level }(\mathrm{km})\end{array}$ & Storm type & Notes \\
\hline $25 \mathrm{Apr}$ & $0600-1200$ & 3.6 & Disorganized MCS & \\
\hline 20 May & $0200-1300$ & 4.4 & Trailing-stratiform MCS & $\begin{array}{l}\text { Disorganized, isolated cells transition to } \\
\text { organized squall-line MCS. }\end{array}$ \\
\hline 23 May & $2000-0500$ & 4.2 & Supercell & $\begin{array}{l}\text { Record hail size for Oklahoma recorded } \\
\text { during this storm system. }\end{array}$ \\
\hline 24 May & $1900-0200$ & 4.3 & Supercell, leading-stratiform MCS & $\begin{array}{l}\text { EF5 tornado reported during this } \\
\text { storm system. }\end{array}$ \\
\hline
\end{tabular}

Gaussian smoother in order to remove texture resulting from ray-to-ray processing of the $K_{\mathrm{DP}}$ field. From this processed two-dimensional field, regional maxima were identified and a watershed segmentation algorithm (a class of feature or "blob" detection algorithms) was used to identify the boundaries and horizontal extent of each $K_{\mathrm{DP}}$ column region [see Roerdink and Meijster (2001) for a review of watershed algorithms]. This method allowed for the identification of $K_{\mathrm{DP}}$ columns of irregular shape, which may or may not share a boundary with other $K_{\mathrm{DP}}$ columns. Within the horizontal bound of each $K_{\mathrm{DP}}$ column, the maximum height of the $K_{\mathrm{DP}}>0.75^{\circ} \mathrm{km}^{-1}$ and $Z_{\mathrm{DR}}>1.0-\mathrm{dB}$ level was identified. These threshold were chosen based on values reported for $K_{\mathrm{DP}}$ and $Z_{\mathrm{DR}}$ columns in previous research (e.g., Loney et al. 2002). The corresponding C-SAPR $K_{\mathrm{DP}}$ threshold of $1.5^{\circ} \mathrm{km}^{-1}$ was increased to account for the inverse proportionality of phase shift to wavelength. Variations of $25 \%$ in each threshold were found to have insignificant effects on the conclusions in the paper.

To identify the maximum height of the $Z_{\mathrm{DR}}$ level explicitly associated with liquid water, additional requirements were made that this level occur where there is a negative vertical gradient in $Z_{\mathrm{DR}}$ (indicating the top of a vertically extended column of positive $\left.Z_{\mathrm{DR}}\right)$ and that this level occur below the homogeneous freezing level (about $9.5 \mathrm{~km}$ above MSL on each day). These requirements were imposed so as to avoid finding levels associated with oblate ice hydrometeors found near the top of the stratiform ice deck that display elevated positive $Z_{\mathrm{DR}}$. This method may still misidentify regions of dendritic ice growth that occur between $-10^{\circ}$ and $-20^{\circ} \mathrm{C}$ as $Z_{\mathrm{DR}}$ columns as a result of the positive $Z_{\mathrm{DR}}$ of oblate ice; however, no such regions were found and no such contamination is expected in the cases studied here. Both $K_{\mathrm{DP}}$ and $Z_{\mathrm{DR}}$ volume above the melting level were calculated by summing the area included in the aforementioned $K_{\mathrm{DP}}$ and $Z_{\mathrm{DR}}$ thresholds, respectively, in a 3-km slab above the melting level.

\section{b. Meteorology}

Four days during MC3E were selected for analysis, each featuring deep convection over Oklahoma and southern Kansas. Some characteristics of storms observed on each day are listed in Table 1 . These days were chosen because all featured deep convection and were sampled by aircraft, suitable for detailed model evaluation. The four cases displayed significant differences in organizational mode and intensity. In some cases, such as 20 and 24 May, the organizational morphology of the prevalent storm systems changed considerably during the observational period.

\section{1) 0700-1100 UTC 25 APRIL 2011 (LATE NIGHT- EARLY MORNING LOCAL)}

Storms initiated along a lower-tropospheric boundary associated with a weak surface low pressure system. The skew $T-\log p$ diagram indicates a linear $0-6-\mathrm{km}$ shear of approximately $30 \mathrm{~m} \mathrm{~s}^{-1}$ (see Fig. 3) with strong uppertropospheric westerly and southerly winds. Such a wind profile has been shown to favor linear squall-line development with leading-stratiform precipitation (Parker and Johnson 2000), and the storms that developed in southern Oklahoma were indeed of this type. However, the storms of interest were located in northern Oklahoma to southern Kansas and developed along a weak low-level baroclinic zone. Convection cells in this region were initially oriented west to east but organized into south-north-oriented lines as they reached maturity. Evidence of both orientations can be seen in the midtropospheric radar plots in Fig. 2.

\section{2) 0700-1100 UTC 20 MAY 2011 (LATE NIGHT- EARLY MORNING LOCAL)}

This case exhibited cellular convection that developed in the early morning (local time) along a dryline generated on 19 May and with synoptic forcing for ascent provided by an approaching upper-level low pressure system. Storms subsequently organized into a linear mesoscale convection system at approximately 0830 UTC. As on 


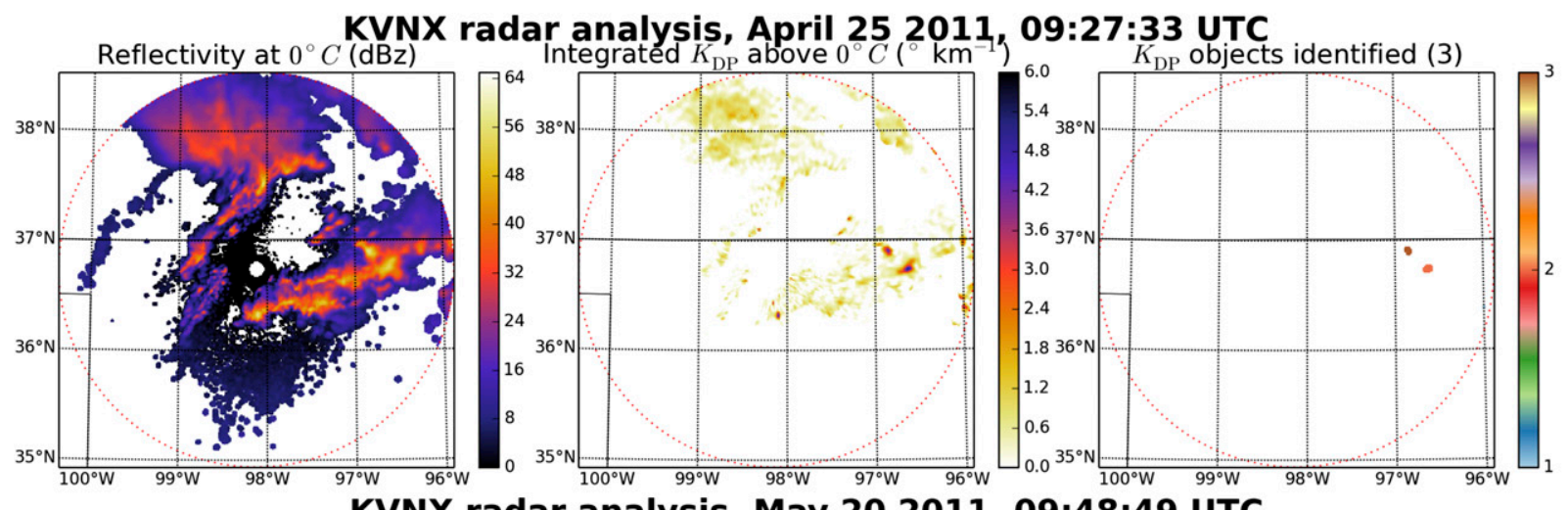

KVNX radar analysis, May 20 2011, 09:48:49 UTC
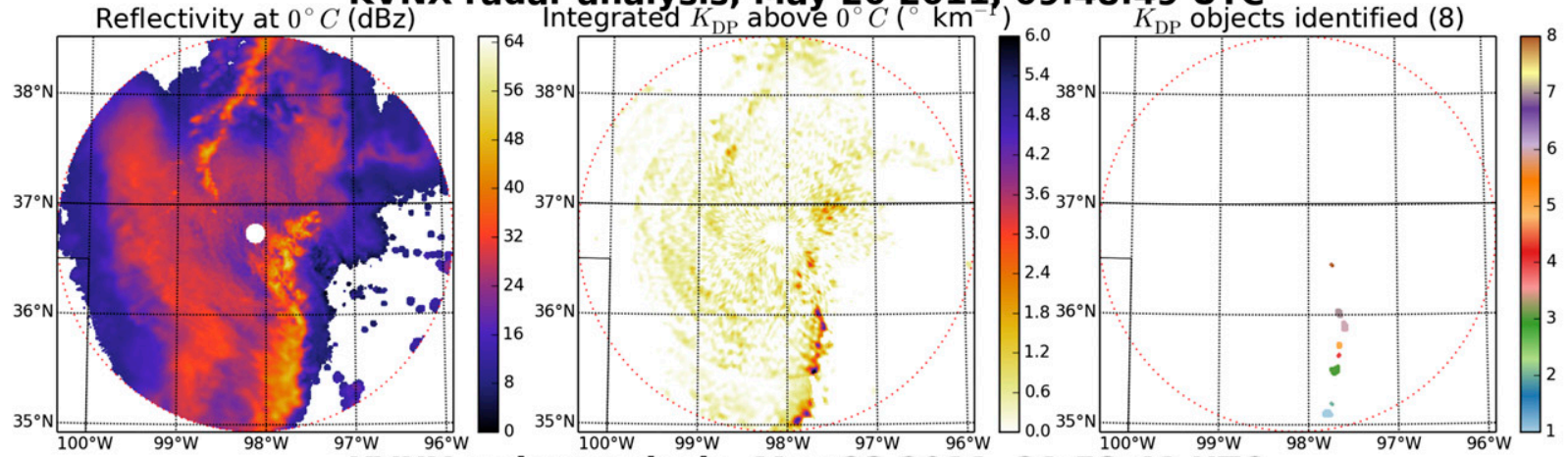

KVNX radar analysis, May 23 2011, 21:53:41 UTC
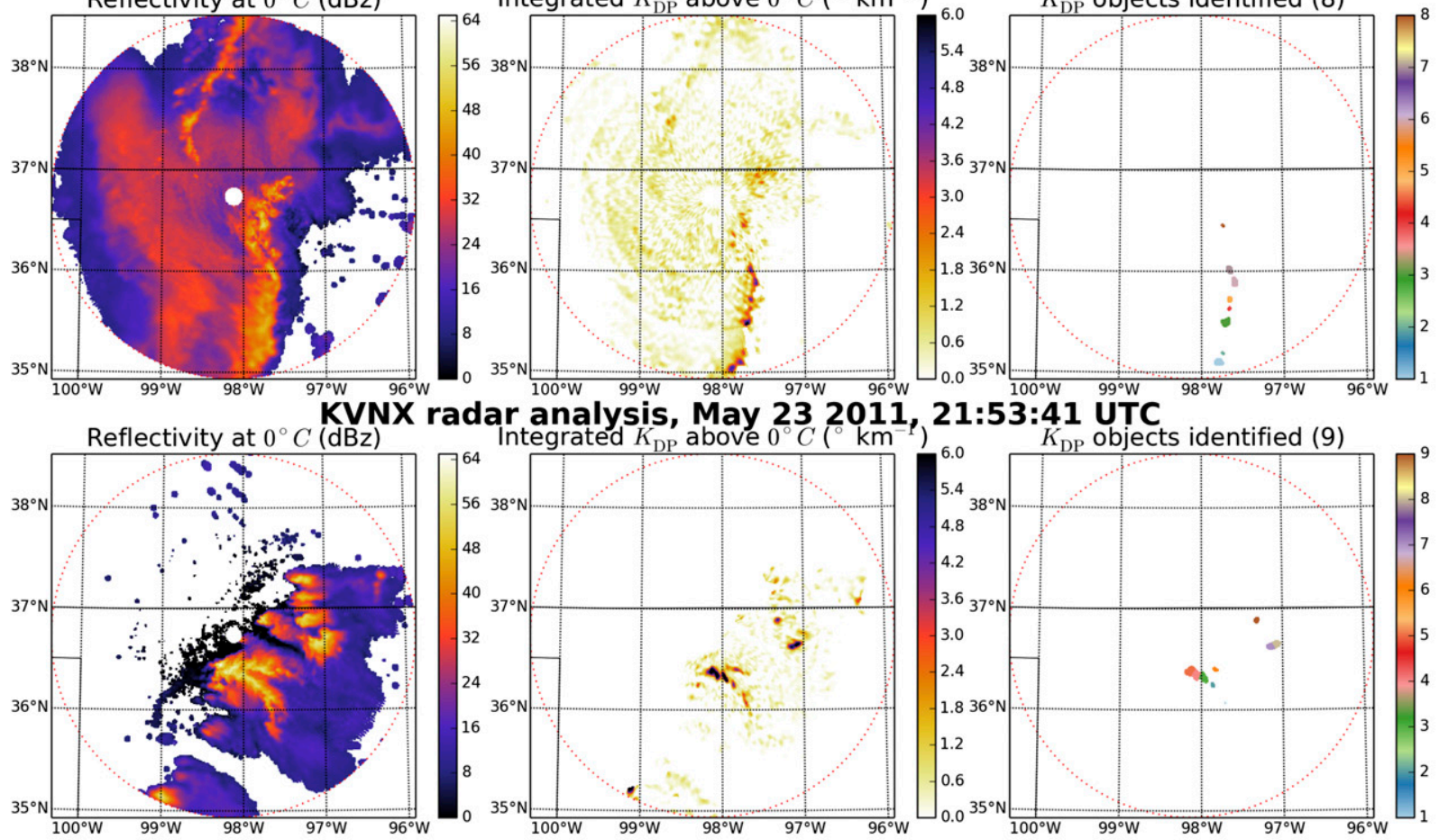

KVNX radar analysis, May 24 2011, 21:39:54 UTC

Reflectivity at $0^{\circ} C(\mathrm{dBz})$
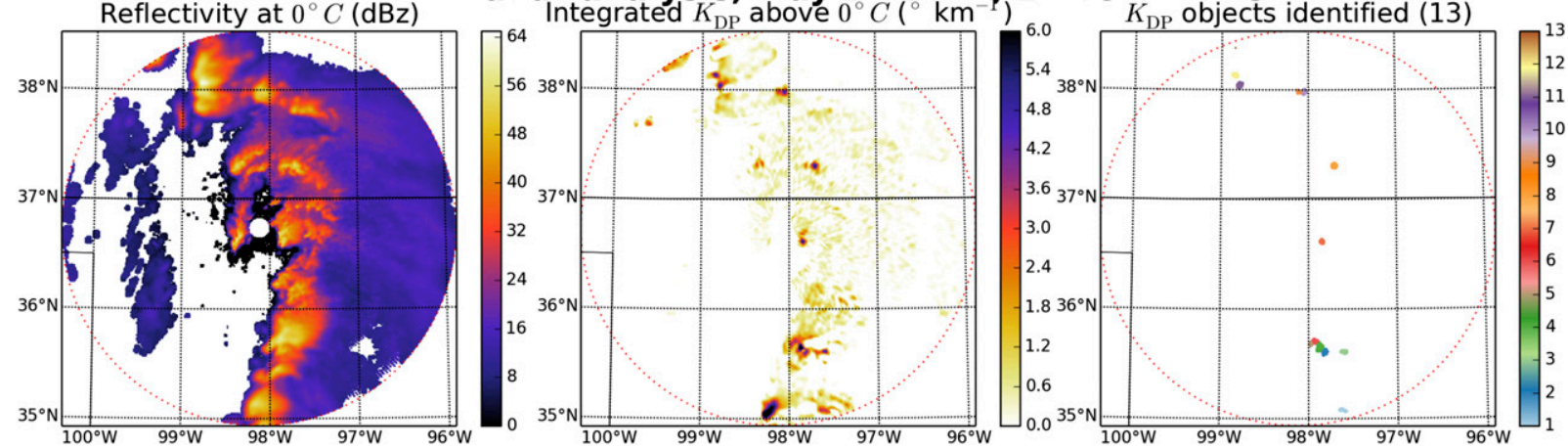

FIG. 2. Examples of radar observations and analysis from KVNX on each of the 4 days in this study. (left) Radar reflectivity at approximately the melting level, (middle) $K_{\mathrm{DP}}$ integrated in a slab above the melting level, and (right) $K_{\mathrm{DP}}$ column objects identified by the algorithm described in this paper. Each object is color coded and the number of objects is listed in the plot title. 

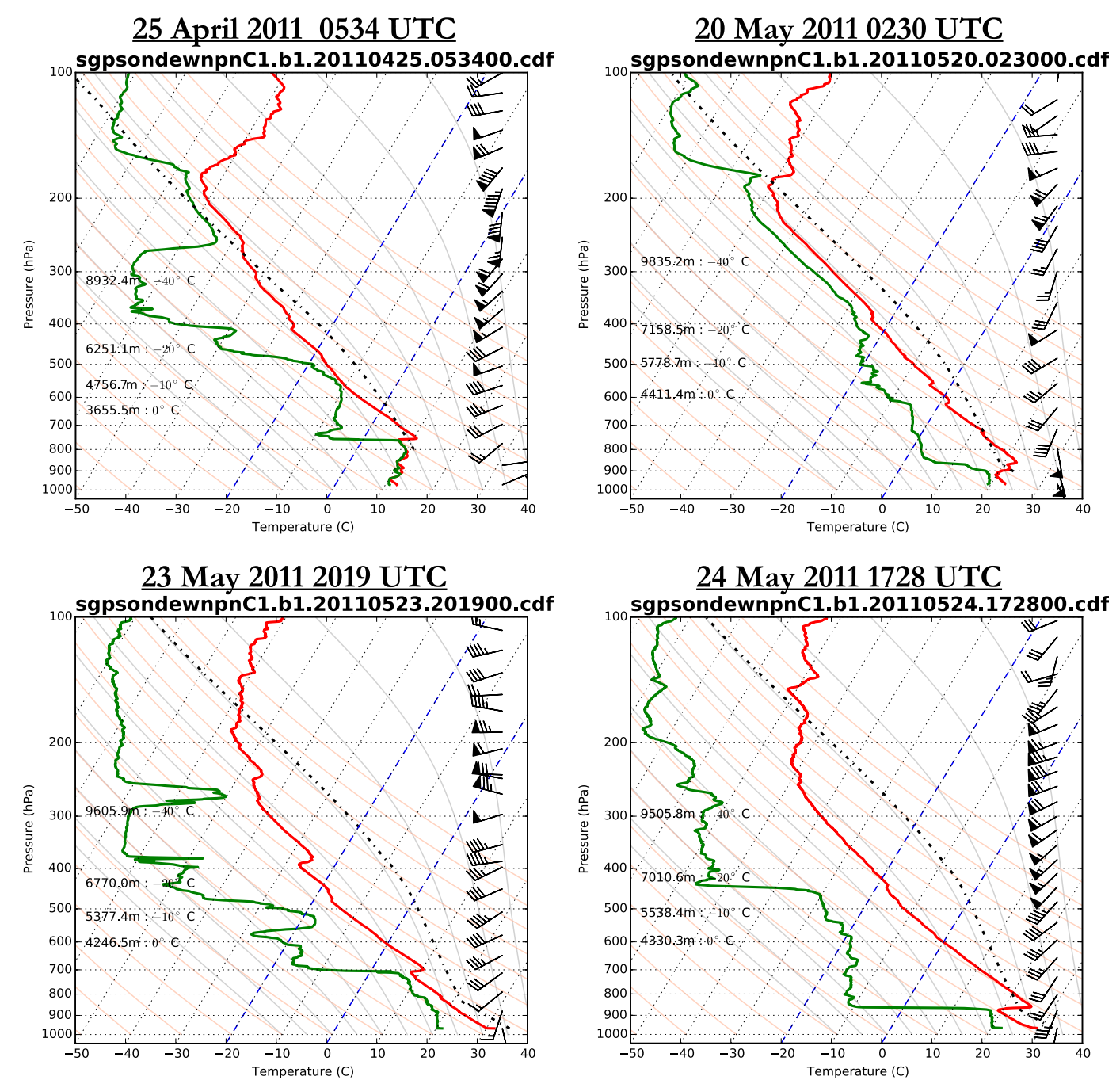

FIG. 3. Soundings from the ARM SGP central facility for each of the 4 days. Times chosen are shortly before radar time series analysis in this study, except for 23 May, which has a sounding from a time closer to storm maturity.

25 April, 0-6-km shear was approximately $30 \mathrm{~m} \mathrm{~s}^{-1}$; however, on this day the surface winds were strongly southerly, and convection matured into "leading line, trailing stratiform" structures (Parker and Johnson 2000). A south-to-north-oriented convection line with trailing stratiform can be clearly seen in the radar imagery in Fig. 2. Later soundings show a well-developed rear-inflow jet as is typical in such storms Biggerstaff and Houze (1991).

\section{3) 2100-0200 UTC 23 MAY 2011 (LATE AFTERNOON-LATE EVENING)}

On 23 May, the upper-level flow was nearly zonal, with a weak short-wave trough located just west of Oklahoma and a weak surface boundary extending from southwest Oklahoma into southeast Kansas. Cellular convection initiated along a dryline located in western Oklahoma and exhibited anvils that expanded rapidly to the east and southeast. By the time the storm had reached maturity, upper-level winds were oriented from northwest to southeast, promoting anvil expansion in that direction (see Fig. 3). Thick stratiform anvil structures can be clearly seen in the radar reflectivity in Fig. 2. Isolated convection in southern Oklahoma dissipated, while storms to the north organized along the surface boundary and eventually produced a northwest-tosoutheast-moving bow echo.

\section{4) 2000-0100 UTC 24 MAY 2011 (LATE AFTERNOON-EARLY EVENING)}

In contrast to the previous day, convection on 24 May developed in association with an approaching upper-level 
trough and deepening surface low pressure system. Convection initiated along the dryline at approximately 1830 UTC, rapidly moved east-northeast, and produced thick stratiform anvils that expanded to the north and east. Cellular and supercellular features later organized into south-to-north-oriented lines that continued to propagate eastward through the remainder of the evening (local time).

\section{Summary of results}

a. Time series observations: KVNX, C-SAPR, LMA, and multi-Doppler updrafts

To illustrate one example of how $K_{\mathrm{DP}}, Z_{\mathrm{DR}}$, updraft mass flux, and lightning flash rates contemporaneously evolve, time series are shown for a single day, 23 May 2011. Time series for the other days analyzed here are made available as online supplemental material (see Figs. S1-S12 in the online supplemental material).

\section{UTC 23 MAY-0500 UTC 24 MAY 2011}

Time series of bulk polarimetric radar analysis from KVNX data collected on 23 May 2011 are shown in Fig. 4 . The $K_{\mathrm{DP}}$ volume above the melting level shows very little signal until approximately 2120 UTC, when it increased dramatically, peaking just before 2200 UTC. Between 2200 and 2330, $K_{\mathrm{DP}}$ volume above the melting level remained elevated, while experiencing considerable fluctuations. Subsequently, $K_{\mathrm{DP}}$ volume decreased before showing three sharp increases peaking at 0045 , 0145, and again at 0400 UTC, respectively. There is inconsistency in terms of the relationship between $K_{\mathrm{DP}}$ volume observed above the melting level and $K_{\mathrm{DP}}$ area at the surface. In particular, the period between 2120 and 2330 UTC showed greater $K_{\mathrm{DP}}$ area at the surface relative to above the melting layer, when compared with the period between 2330 and 0200 UTC. C-SAPR data from storms on 23 May (Fig. 5) agreed well with KVNX in both magnitude and timing of the presence of $K_{\mathrm{DP}}$ observed above the melting level, but data are temporally limited for this case because of a radar malfunction. Rain rates above both the 40 and $90 \mathrm{~mm} \mathrm{~h}^{-1}$ thresholds are well correlated with one another and generally followed the evolution of $K_{\mathrm{DP}}$ volume above the melting level, though limited data exist for comparison.

The $Z_{\mathrm{DR}}$ volume above the melting level is seen to have increased before elevated positive values of $K_{\mathrm{DP}}$ became evident. This finding is in agreement with use of $Z_{\mathrm{DR}}$ columns as an early observational signal of deep convection updrafts (Bringi et al. 1991). The $Z_{\mathrm{DR}}$ volume above the melting level followed the general trend of $K_{\mathrm{DP}}$ volume, but maxima were not always contemporaneous. For example, the peak in $K_{\mathrm{DP}}$ volume at $0145 \mathrm{UTC}$ is visible in $Z_{\mathrm{DR}}$ volume, but its shape and strength relative to other peaks is different than for $K_{\mathrm{DP}}$; $K_{\text {DP }}$ column heights are generally higher than on 25 April or 20 May, though lower than 24 May, with a mode in the height distribution at about $6 \mathrm{~km}$, or almost $2 \mathrm{~km}$ above the melting level. The $Z_{\mathrm{DR}}$ volume above the melting level is generally much greater than $K_{\mathrm{DP}}$ volume above the melting level. This can be explained, in part, by noting that $K_{\mathrm{DP}}$, unlike $Z_{\mathrm{DR}}$, requires significant concentrations of liquid hydrometeors, and may therefore be absent in cases where size sorting produces low concentrations of large droplets, for example. However, choice of $K_{\mathrm{DP}}$ and $Z_{\mathrm{DR}}$ thresholds is likely also a factor in comparison between respective volumes above the melting level. There are generally more $K_{\mathrm{DP}}$ columns that exceed $7 \mathrm{~km}$ in height during the later period of the storm system (after 0000 UTC) compared with the earlier period of the storm system. The $K_{\mathrm{DP}}$ columns detected in the C-SAPR radar show generally good agreement with KVNX in median column height.

LMA flash analysis, shown in Fig. 6 together with polarimetric radar analysis from KVNX, show that total lightning flash activity appears to lag local maxima in $K_{\mathrm{DP}}$ volume in time but generally appears better correlated temporally with $Z_{\mathrm{DR}}$ volume above the melting level. Total flash activity peaks at values greater about equal to those observed on 20 May, despite much lower values of $K_{\mathrm{DP}}$ volume above the melting level.

Comparison of $K_{\mathrm{DP}}$ from C-SAPR with multi-Doppler wind retrievals is shown in Fig. 7. Lag correlation (not shown) peaks at $r_{\tau}=0.93$ when updraft mass flux at $0^{\circ} \mathrm{C}$ precedes the onset of $K_{\mathrm{DP}}$ volume above the melting level by at approximately $14 \mathrm{~min}$ (compared to a correlation of $r=0.79$ for zero lag). This appears to echo results shown in Fig. 6, where the presence of $K_{\mathrm{DP}}$ volume above the melting level can be seen to lag both lightning activity and $Z_{\mathrm{DR}}$ volume above the melting level. One may hypothesize by extension that updraft statistics might be correlated with $Z_{\mathrm{DR}}$ above the melting level on this day, and thus in this case, $Z_{\mathrm{DR}}$ may better track the early updraft than $K_{\mathrm{DP}}$. Whether or not this is the case, the fact that a lag in correlation between $K_{\mathrm{DP}}$ above the melting level and other observational metrics is observed on this day, but not others, suggests that this lag may be related to storm morphological and microphysical properties unique to the 23 May case.

\section{b. Statistical correlations}

In order for meaningful comparison to be made between observations and simulations, aggregated statistics of relationships between storm-relevant variables should be employed. This reduces the effects of spatial 
NEXRAD $K_{\mathrm{DP}}$ and $Z_{\mathrm{DR}}$ statistics, May 23, 2011
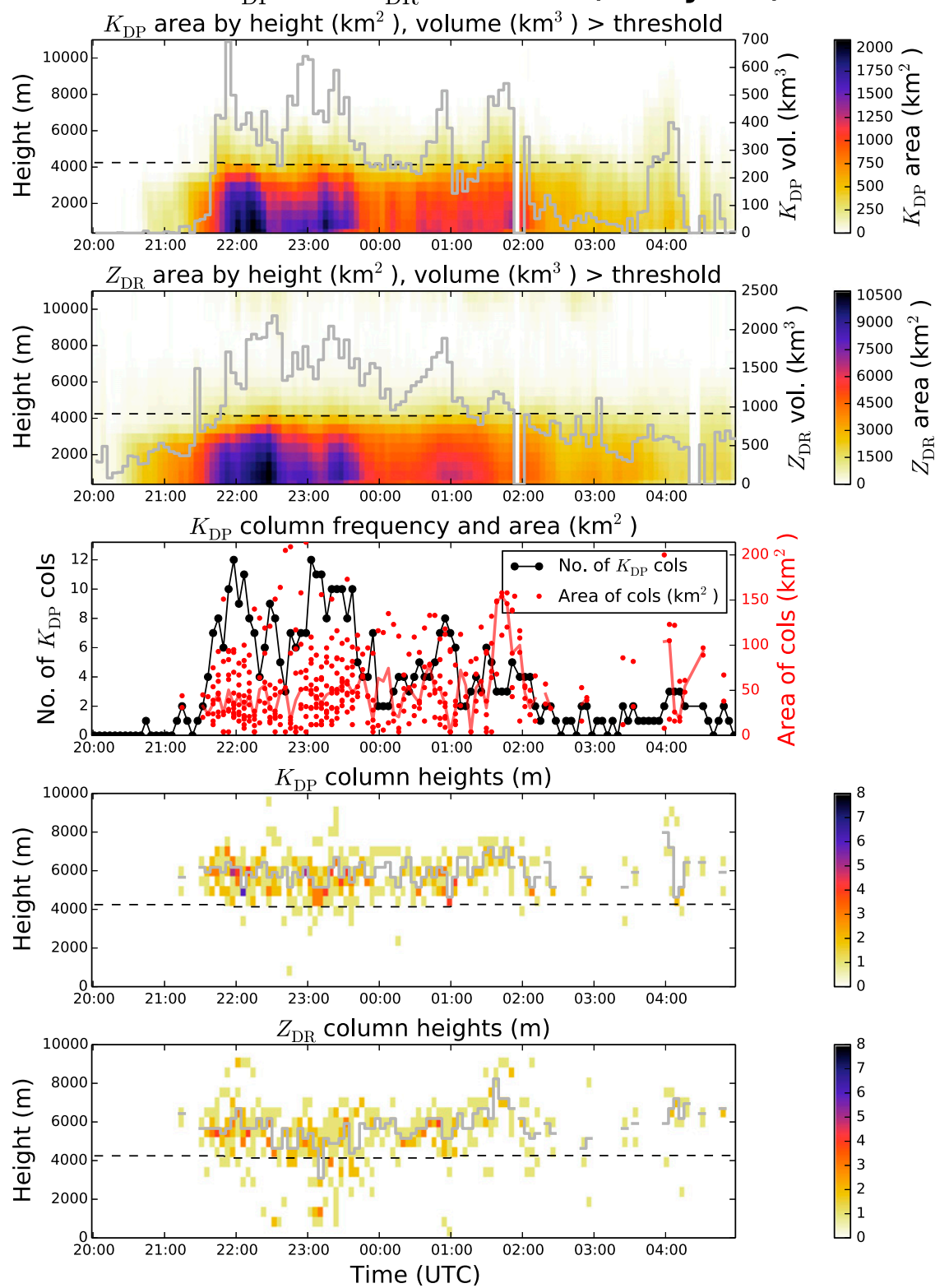

FIG. 4. Analysis of polarimetric observations from the S-band Vance WSR-88D on 23 May 2011. (top) Area with $K_{\mathrm{DP}}>0.75^{\circ} \mathrm{km}^{-1}$ at each level (filled colors), volume with $K_{\mathrm{DP}}>0.75^{\circ} \mathrm{km}^{-1}$ above the melting level (gray line), and the melting level (dotted line). (second from top) As in (top), but for $Z_{\mathrm{DR}}>1 \mathrm{~dB}$. (middle) Number of $K_{\mathrm{DP}}$ columns detected (black) and area of each column (red). (second from bottom) Maximum height of the $K_{\mathrm{DP}}>0.75^{\circ} \mathrm{km}^{-1}$ contour for each $K_{\mathrm{DP}}$ column (colored histogram), median height (gray line), and melting level (dotted line). (bottom) As in (second from bottom), except for the maximum height of the $Z_{\mathrm{DR}}>1-\mathrm{dB}$ contour for each $K_{\mathrm{DP}}$ column. Domain is red circle in Fig. 1.

and temporal phase errors related to the timing and propagation of the simulated storm system. We note, however, that it is unreasonable to assume that a linear correlation provides the best statistical analysis for relationships that are undoubtedly nonlinear, and so
Spearman rank correlation coefficients $\rho$ are shown together with Pearson correlation coefficients $r$.

Figure 8 shows volumes that exceed the $K_{\text {DP }}>0.75^{\circ} \mathrm{km}^{-1}$ threshold in a $2-\mathrm{km}$ slab above the melting level compared with similar volumes observed 


\section{C-SAPR $K_{\mathrm{DP}}$ \& Rainrate statistics, May 23, 2011}
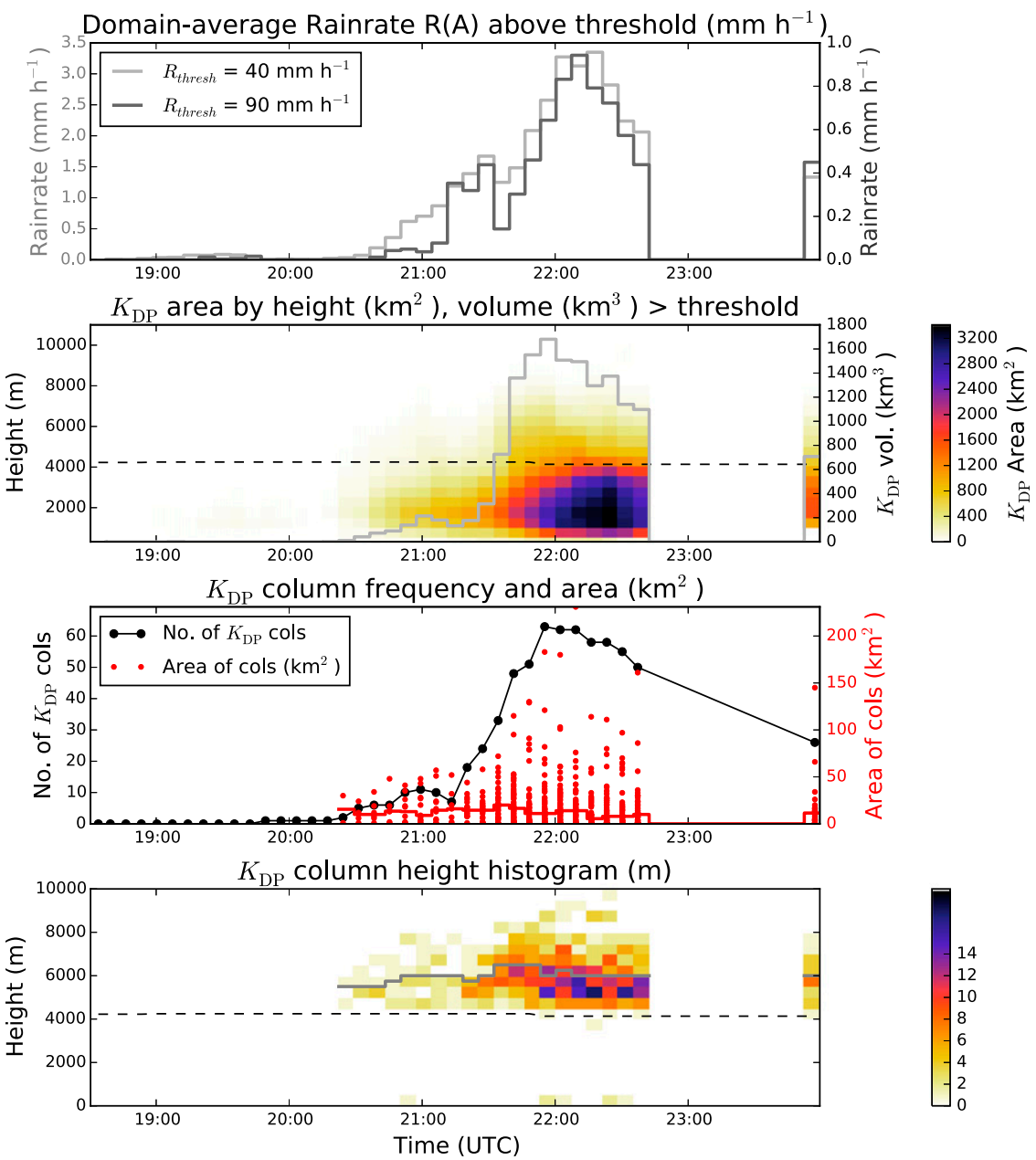

FIG. 5. Analysis of polarimetric observations from the C-SAPR radar on 23 May 2011. As in Fig. 4, but with $K_{\mathrm{DP}}$ volume threshold increased to $1.5^{\circ} \mathrm{km}^{-1}$ and with $Z_{\mathrm{DR}}$ analysis omitted, owing to radar characteristics (see text). Domain is blue circle in Fig. 1.

at low levels (a 2-km slab above the surface). The $K_{\mathrm{DP}}$ volume above the melting level can be considered a $K_{\text {DP }}$ signal associated with deep convection updrafts, whereas the low-level volume is more closely related to convective rain rates. The two quantities plotted together thus provide a basis for insight into how much of convective rainfall is associated with deep convection updrafts, in essence providing a measure of convective intensity at a given time as well as the likelihood of mixed-phase processes in deep convection. In Fig. 8 these data are presented for each time observed using the KVNX radar, with all plots sharing an axis ratio of 1:4.5 between $K_{\mathrm{DP}}$ volume above the melting level and $K_{\mathrm{DP}}$ volume at low levels. In addition, data from each day are scaled so that plots are directly comparable, allowing for both comparison of ratio of low-level $K_{\mathrm{DP}}$ to high-level $K_{\mathrm{DP}}$ as well as temporal evolution of that ratio and low and high $K_{\mathrm{DP}}$ volumes. In these figures, points closer to the lower-right section of the plots can be considered more closely associated with concurrent deep convective updrafts than points closer to the upper-left section.

Data from 25 April in Fig. 8 show a generally high ratio of $K_{\mathrm{DP}}$ at low level to $K_{\mathrm{DP}}$ at high levels. This is in keeping with other metrics such as lightning and updraft mass flux that suggest that convection was weaker on this day compared with others. On the other hand, 20 May displays great variability in this deep convection $K_{\mathrm{DP}}$ ratio, in agreement with conclusions from lightning data as well as $K_{\mathrm{DP}}$ column heights recorded at this time (see online supplemental material time series plots S5S8 for details). Specifically, the relationship between 


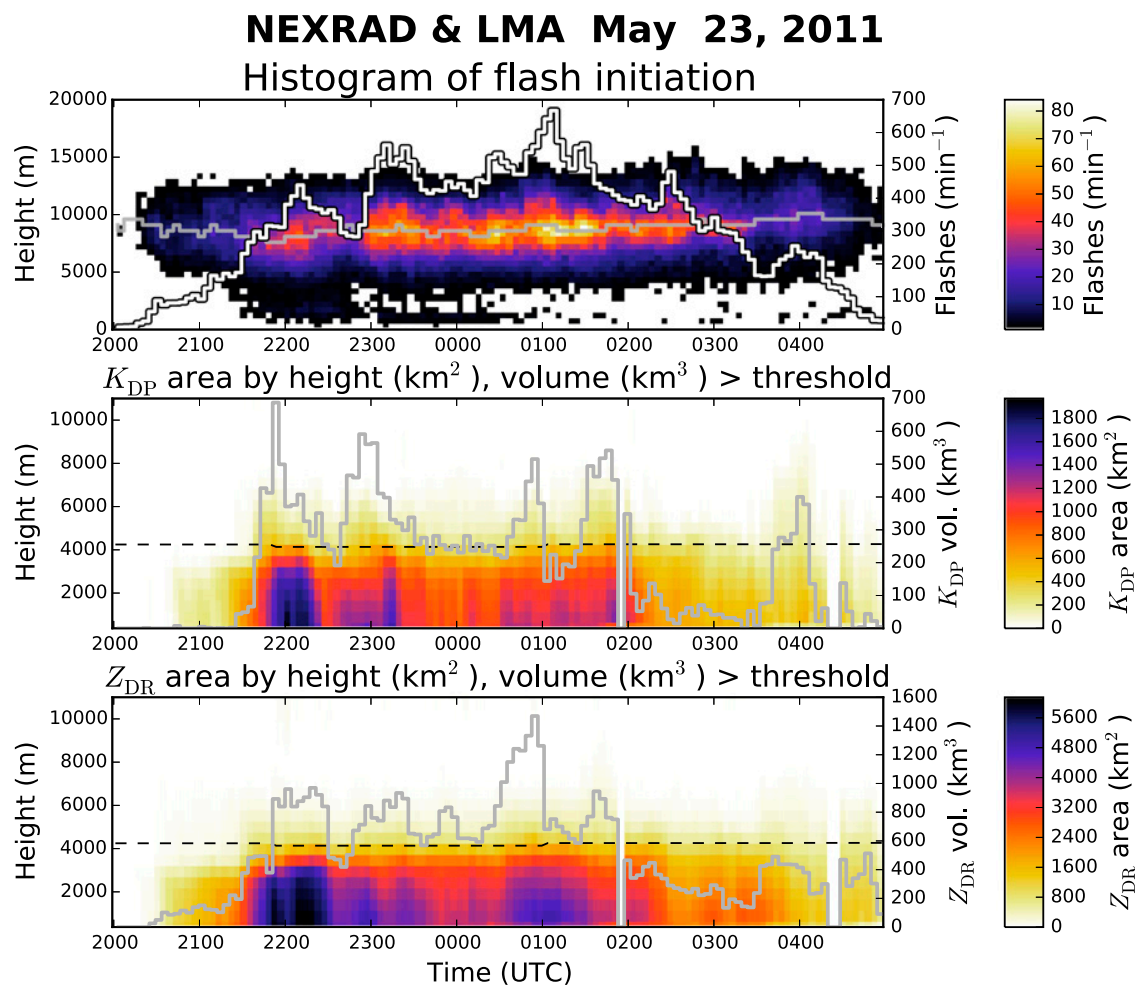

FIG. 6. As in Fig. 4, however (top) shows time-height histogram of lightning flash initiation from the LMA (filled colors), together with time histogram of total flash rate (white line) and median height of initiation (gray line). Domain is overlap of yellow and red circles in Fig. 1.

low-level $K_{\mathrm{DP}}$ and high-level $K_{\mathrm{DP}}$ shows a stronger deep convective updraft signature before 0730 UTC, which is associated with the more intense lightning and higher $K_{\mathrm{DP}}$ columns observed during this time, associated with largely disorganized cellular and multicellular convection. This is in contrast to the strongly organized convection of the trailing-stratiform MCS that follows. Thus, in cases such as 20 May where convective morphology changes so dramatically, $K_{\mathrm{DP}}$ volume alone is insufficient to characterize the intensity of deep convection, although both the ratio of high- and low-level $K_{\mathrm{DP}}$ signals as well as the heights of $K_{\mathrm{DP}}$ columns do provide some indication of these changes. Also, 23 May features variability in the relationship observed between high- and low-level $K_{\mathrm{DP}}$. In this case, later cells appear to be more characteristic of deep convective updrafts. Here 24 May features a generally smaller ratio of $K_{\mathrm{DP}}$ at low levels to $K_{\mathrm{DP}}$ at high levels, indicating consistent deep convective updrafts, in agreement with both lightning frequency and updraft mass flux, which are the highest of the 4 days considered. Later times show slightly increased deep convection character as well as higher $K_{\mathrm{DP}}$ columns (see comparison in Fig. 9), a shift that is contemporaneous with the shift in storm morphology from supercellular storms to an intense leading-stratiform squall line. It bears noting that increased organization on this day is associated with an increased intensity of $K_{\mathrm{DP}}$ and lightning metrics shown here- the opposite of the trend found for 20 May.

Figure 9 shows $K_{\mathrm{DP}}$ column heights as detected by KVNX and C-SAPR for each of the 4 days investigated. As previously discussed, results from KVNX suggest that 24 May features the strongest convection of the 4 days, followed by 23 and 20 May and 25 April, in roughly that order. Heights of $K_{\mathrm{DP}}$ columns range from just above the melting layer to $5 \mathrm{~km}$ above the melting layer, in the case of some $K_{\mathrm{DP}}$ columns detected on 24 May. The tails of these distributions are uncertain, as beamwidth effects may result in significant exaggeration of the maximum height of features far from the radar. Assuming a simple linear model of resolution and uncertainty error that increases with distance, cumulative probability distributions of $K_{\mathrm{DP}}$ column height were calculated. The heights of the $10 \%(20 \%)$ probability levels [i.e., $10 \%(20 \%)$ probability of a given column height exceeding this value] are $5.7(5.3) \mathrm{km}$ for 25 April, $7.3(6.6) \mathrm{km}$ for 20 May, 6.8 (6.3) km for 23 May, and 
Multi-Doppler Updraft \& C-SAPR $K_{\mathrm{DP}}$ statistics, May 23, 2011

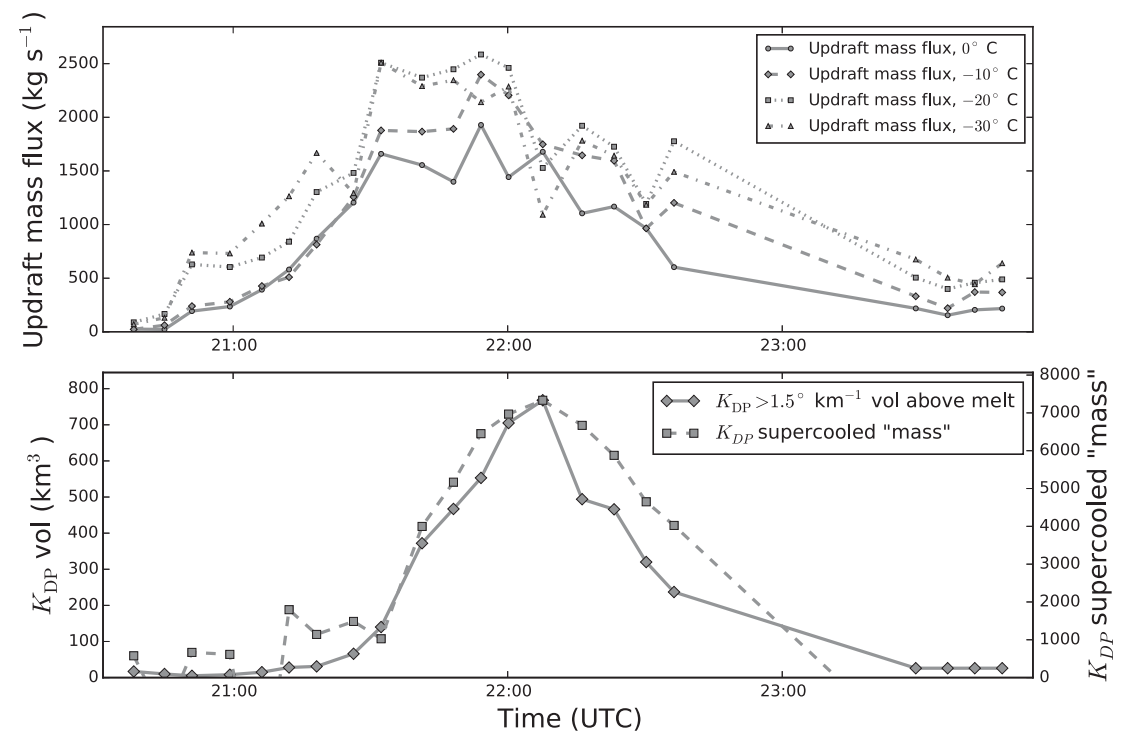

FIG. 7. Updraft ( $w>1 \mathrm{~m} \mathrm{~s}^{-1}$ ) mass flux at four levels from multi-Doppler wind retrieval, $K_{\mathrm{DP}}>1.5^{\circ} \mathrm{km}^{-1}$ volume above the melting level, and $K_{\mathrm{DP}}$ "supercooled mass" from the CSAPR radar (see text) on 23 May 2011. Domain is black square in Fig. 1.

7.6 (7) $\mathrm{km}$ for 24 May. These values are suggested as conservative estimates of maximum column heights recorded, given uncertainties caused by increased resolution error with distance from the KVNX radar.

Results from C-SAPR (also shown in Fig. 9) match KVNX results quite well despite differences in radar domain and resolution. Modes of the $K_{\mathrm{DP}}$ column height distributions are generally in very good agreement. The $K_{\mathrm{DP}}$ column heights recorded in the KVNX data for 20 May suggest that the heights of $K_{\mathrm{DP}}$ columns may vary significantly within the course of a day in accordance to changing morphology and intensity of convection. For example, in the case of 20 May, a decrease in both height and variability of $K_{\mathrm{DP}}$ column heights is related to a change from disorganized convection cells to a trailing-stratiform MCS with generally less intense convection. On 24 May, a similar organizational process occurs, with distinct supercellular storms merging into a leading-stratiform squall line after 2230 UTC. In this case the change in storm morphology to a linearly organized state is associated with an increase in intensity of the metrics here associated with deep convection.

Multi-Doppler wind retrieval-derived updraft mass flux at the environmental $-10^{\circ} \mathrm{C}$ level shows good $(r>0.8)$ correlation with C-SAPR $K_{\mathrm{DP}}$ volume above the melting level for 25 April and 20 and 23 May (Fig. 10). Here 24 May shows poor correlation, likely attributable to issues with wind retrieval on this day, including severe attenuation of X-and C-band radars as well as problems with Doppler dealiasing. In some cases, $K_{\mathrm{DP}}$ is shown to correlate better with updraft mass flux at different levels. For example, on 25 April, $K_{\mathrm{DP}}$ volume is better correlated with updraft mass flux at the $-20^{\circ}$ and $-30^{\circ} \mathrm{C}$ levels and on 20 May, $K_{\mathrm{DP}}$ volume is best correlated with updraft mass flux at the $0^{\circ} \mathrm{C}$ level (see Fig. 7 as well as Figs. S4, S8, and S12 in the online supplemental material). We decline to offer a hypothesis on this peculiarity, as a conclusive answer might require a detailed analysis of uncertainties in the multi-Doppler wind retrievals for each day studied, which is beyond the scope of the current study.

The $K_{\mathrm{DP}}$ volume above the melting level, as detected by C-SAPR, is well correlated with intense surface rain rates estimated via the $\mathrm{R}(\mathrm{A})$ method of Ryzhkov et al. (2014) and Giangrande et al. (2014). These values are shown together in Fig. 11. All days show correlation coefficients of $r>0.75$.

To investigate whether strong updrafts appear in the vicinity of $K_{\mathrm{DP}}$ columns, a joint histogram of $K_{\mathrm{DP}}$ column heights as detected by the C-SAPR radar and coincident maximum updraft speed, as retrieved by multi-Doppler wind analysis, is shown in Fig. 12. Maximum retrieved updraft speed $\left(w>1 \mathrm{~m} \mathrm{~s}^{-1}\right)$ is collected in the $3 \mathrm{D}$ columnar region defined by the $2 \mathrm{D} K_{\mathrm{DP}}$ column object boundaries; $K_{\mathrm{DP}}$ column height shows a weak correlation $(r=0.37)$ with multi-Doppler retrieved updraft speed. One hypothesis for this weak 
Comparison of $K_{\mathrm{DP}}>0.75^{\circ} \mathrm{km}^{-1}$ volume above melting level \& at low levels
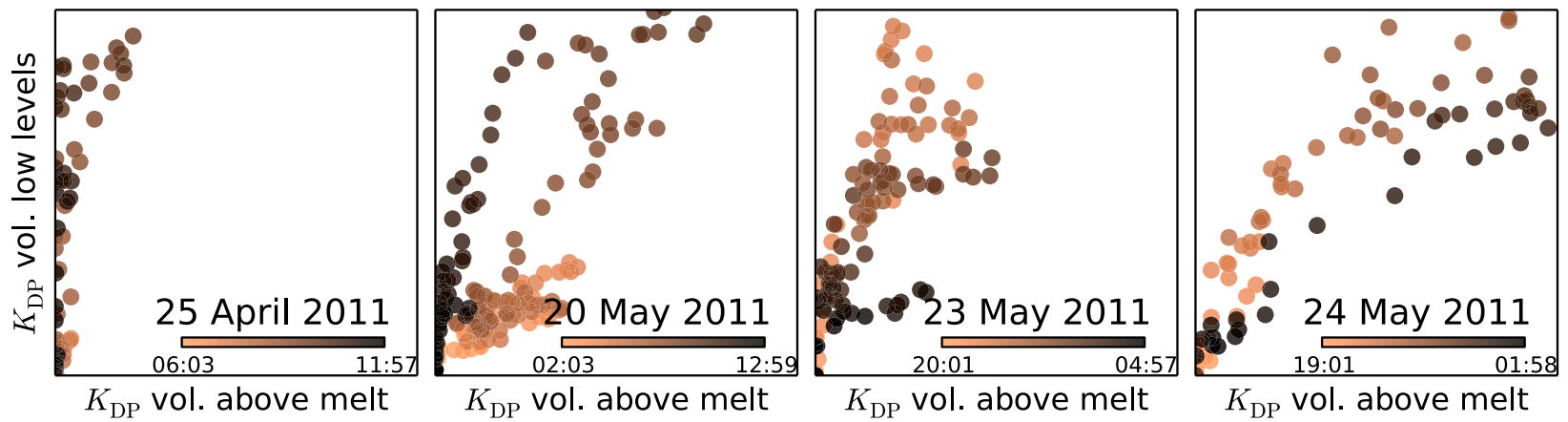

FIG. 8. Scatterplot of $K_{\mathrm{DP}}>0.75^{\circ} \mathrm{km}^{-1}$ volume above the melting level and $K_{\mathrm{DP}}>0.75^{\circ} \mathrm{km}^{-1}$ volume in the bottom two kilometers above the surface. Colors indicate observation time, with darker colors indicating later observation times. Each plot is scaled identically, with a ratio of 1:4.5 for the axes of $K_{\mathrm{DP}}$ above the melting level and $K_{\mathrm{DP}}$ at low levels, respectively. Because of this scaling, units are not shown.

correlation is that true correlations between these variables may occur with some spatial and temporal lag. Loney et al. (2002), for example, noted that updrafts and the hydrometeors that produce $K_{\mathrm{DP}}$ columns are likely spatially distinct features, at least in the absence of resolution-broadening of the $K_{\mathrm{DP}}$ column. Furthermore, updrafts are likely to be tilted or even helical depending on shear and storm helicity; these effects are likely to impact the location and shape of polarimetric features of deep convection updrafts (e.g., Kumjian and Ryzhkov 2009). A more robust approach may be to search for updrafts in the spatial region surrounding a $K_{\mathrm{DP}}$ column or to analyze the full life cycle of $K_{\mathrm{DP}}$ columns from a Lagrangian perspective. This last approach would also reveal any correlations between $K_{\mathrm{DP}}$ and updraft strength that lag in time. A stronger correlation is observed between $K_{\mathrm{DP}}$ column area and maximum updraft speed, but this may be partly explained by noting that no matter the region chosen, larger areas are more likely to result in a greater maximum updraft speed than smaller areas.

Each day featured widely varying $K_{\mathrm{DP}}$ column heights as well as substantial variability in $K_{\mathrm{DP}}$ volume, updraft, and lightning statistics; however, common characteristics can be identified for each day. Figure 13 shows a clear relationship between $K_{\mathrm{DP}}$ column height and $K_{\mathrm{DP}}$ column area for columns detected by KVNX. C-SAPR results, also shown in Fig. 13, generally match these results, although column areas are not as great as in the KVNX data, likely because the poorer resolution of the KVNX data exaggerates column size and also results in the apparent merging of columns. Spread in the joint distribution of $K_{\mathrm{DP}}$ column area and height can be explained either by resolution effects or variations in the area-height relationship over the life cycle of a convection cell or both. Evaluating this last possible explanation requires analysis of the full life cycle of convective cells in a Lagrangian framework.

The $K_{\mathrm{DP}}$ column height is also correlated with height of coincident $Z_{\mathrm{DR}}$ features (Fig. 14). This correlation indicates that when $K_{\mathrm{DP}}$ columns are present, $Z_{\mathrm{DR}}$ columns also tend to be present; $Z_{\mathrm{DR}}$ height tends to be lower than $K_{\mathrm{DP}}$ height partly from anomalous reduction of $Z_{\mathrm{DR}}$ values from differential attenuation or the presence of hail in the radar volume or both. Analysis of $K_{\mathrm{DP}}$ and $Z_{\mathrm{DR}}$ volumes above the melting level (see top two panels of Fig. 4) suggest that deep convective signatures of $K_{\mathrm{DP}}$ and $Z_{\mathrm{DR}}$ evolve semiindependently. As such, it is likely that the presence of $K_{\mathrm{DP}}$ and $Z_{\mathrm{DR}}$ columns are not strictly contemporaneous or spatially collocated and one may draw similar conclusions from previous studies (Loney et al. 2002; Kumjian et al. 2014a).

Finally, the relationships between lightning total flash rate and $K_{\mathrm{DP}}$ and $Z_{\mathrm{DR}}$ volumes are shown in Fig. 15 to further explore the relationship between the polarimetric signals associated with mixed-phase processes in deep convection updrafts and lightning, a phenomenon physically linked with such processes in continental convection. For all 4 days, a positive correlation is found between $K_{\mathrm{DP}}$ volume above the melting level and total flash density, though correlation is only moderate and highly variable across the 4 days studied (for an example of collocation of lightning flashes and $K_{\mathrm{DP}}$ columns; see Fig. S13 in the online supplemental material). Interestingly, data from both 20 May during the disorganized phase of convection before 0730 UTC and data from 23 May indicate a lagged correlation (not shown) of approximately $r=0.6$ at 10 -min lag (i.e., lightning peaks $10 \mathrm{~min}$ after $K_{\text {DP }}$ volume above the melting layer does, on average). 


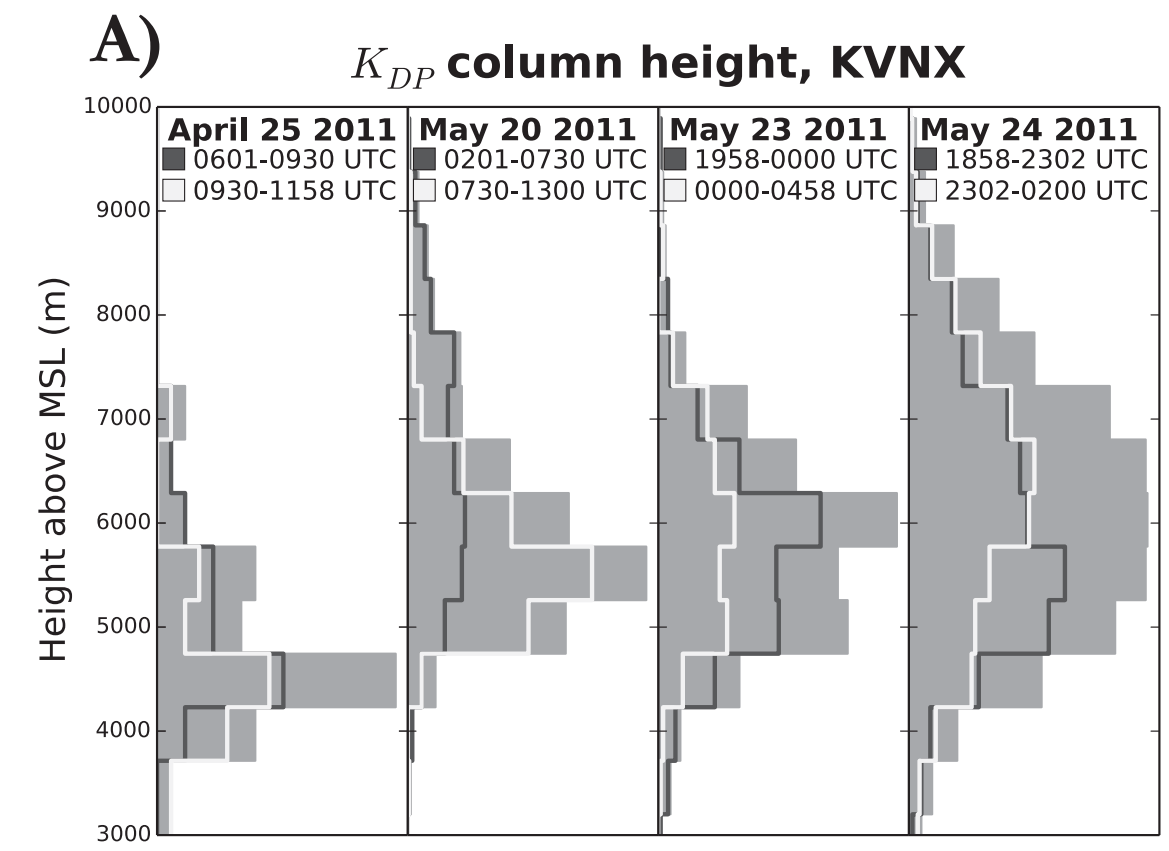

B) $\quad K_{D P}$ column height, C-SAPR

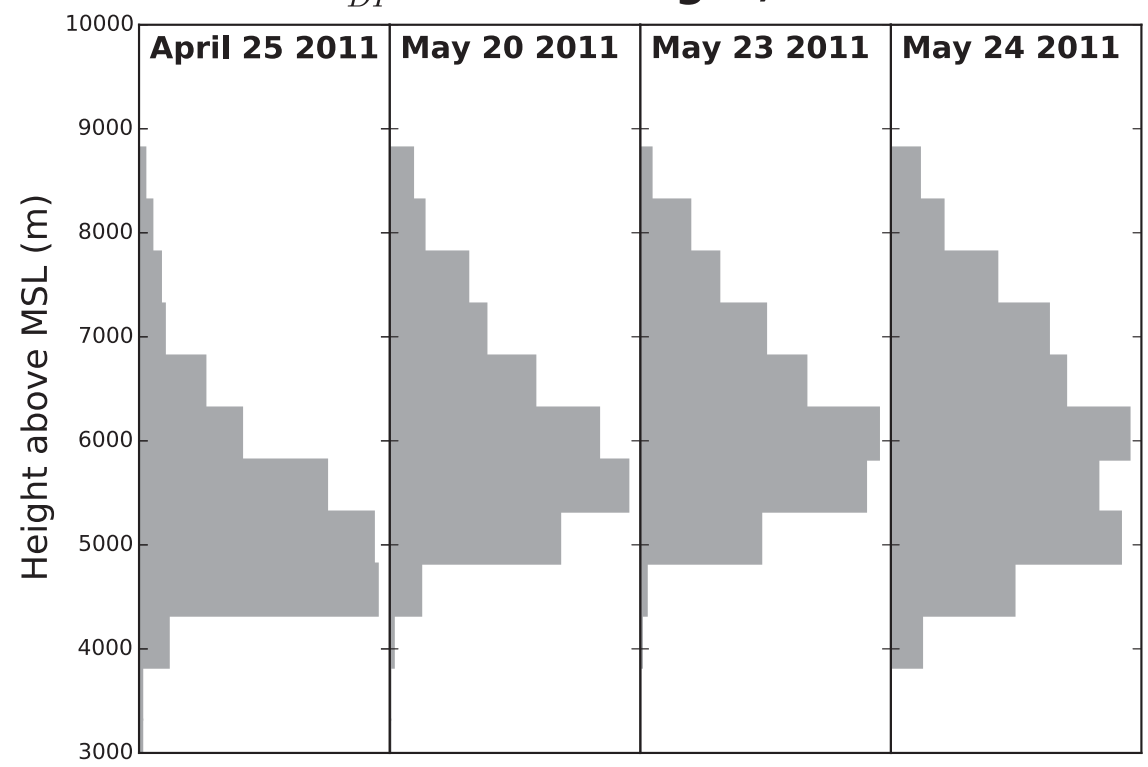

FIG. 9. Histogram of $K_{\mathrm{DP}}$ column-top height as detected by (a) the KVNX radar and (b) the C-SAPR radar for the 4 days of the study. Also shown as white and black lines in (a) are subjectively selected subsamples of the full histogram to demonstrate nonstationarity of $K_{\mathrm{DP}}$ column height statistics.

This lagged correlation underscores a need for treatment of the full updraft life cycle in order to better ascertain the relationships between lightning, $K_{\mathrm{DP}}$ above the melting level, and updraft strength. The $Z_{\mathrm{DR}}$ volume above the melting level also shows correlation with flash rates on all days except 20 May, where resolution effects produce anomalously large $Z_{\mathrm{DR}}$ volume above the melting layer. On 24 May, periods of substantial differential attenuation and the possible presence of hail in the radar volume results in many samples with copious lightning flash activity but relatively small $Z_{\mathrm{DR}}$ volume above the melting level. 


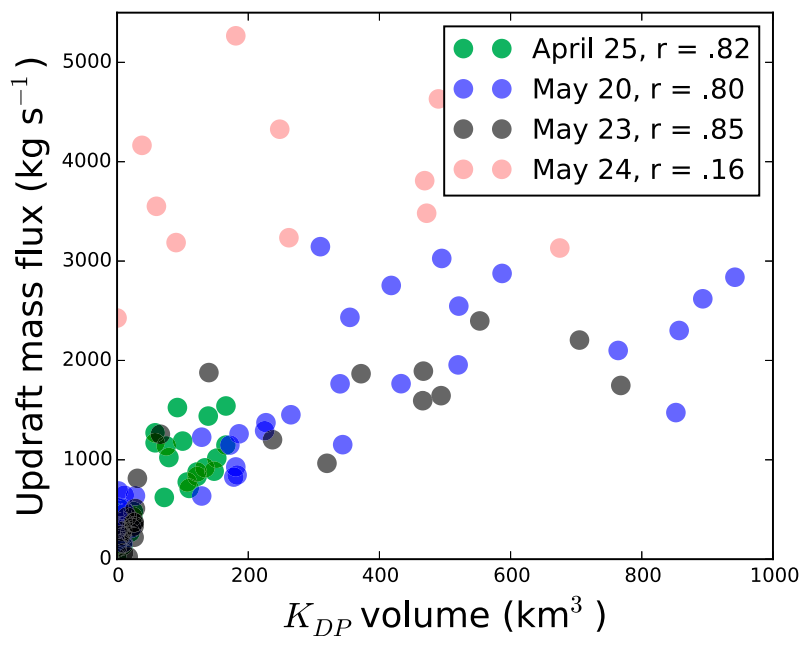

FIG. 10. Updraft mass flux at $-10^{\circ} \mathrm{C}$ from multi-Doppler wind retrieval vs $K_{\mathrm{DP}}>1.5^{\circ} \mathrm{km}^{-1}$ volume above the melting level. Domain is black square in Fig. 1. Colors as indicated in legend, where linear correlation coefficients are also provided.

\section{Discussion}

The strong link seen between $K_{\mathrm{DP}}$ observed above the melting level and updraft statistics in three out of four cases supports our working hypothesis that $K_{\mathrm{DP}}$ is a useful proxy for deep convection updrafts. Detail of the $K_{\mathrm{DP}}$ signal also elucidates information relevant to changing storm morphology and, likely, updraft microphysics. Lightning flash rates also show that $K_{\mathrm{DP}}$ and lightning flash activity do not always display a simple covariance, and the relationship between these variables may depend on the morphological characteristics of the convection that produces them. For example, early disorganized convection cells on 20 May appear more electrically active for a given $K_{\mathrm{DP}}$ volume above the melting level. This especially active period, in turn, occurs at a time when $K_{\mathrm{DP}}$ volume above the melting level is large relative to $K_{\mathrm{DP}}$ volume at low levels, indicating an increased deep convective character of the storm system. This early phase of storm activity on 20 May also displays lagged correlations between $K_{\mathrm{DP}}$ volume and lightning flash activity. Similarly lagged relationships are seen for observations on 23 May but are not significantly for 25 April or 24 May. We hypothesize that lagged correlation occurs at the scale of individual updraft cells and, thus, may not be evident in cases where many cells exist at varying points in their life cycles. In cases such as early 20 May and throughout 23 May, overall lag may be evident by virtue of updraft cells with temporally correlated life cycles. On 20 May it is unclear what causes this correlation; however, on 23 May multiple convection cells initiate almost simultaneously along a dryline, in comparison with organized MCS squall lines occurring later on

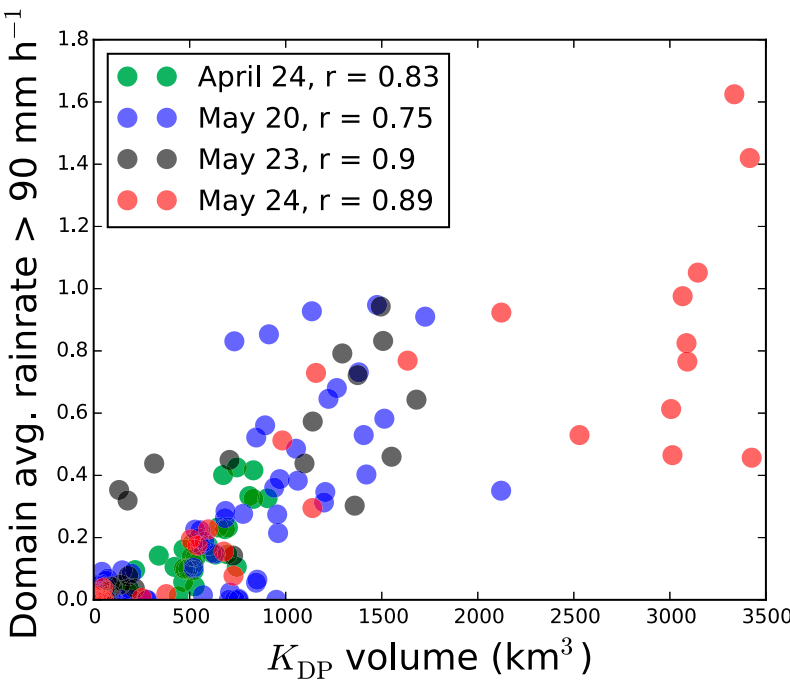

FIG. 11. C-SAPR $K_{\mathrm{DP}}>3.5^{\circ} \mathrm{km}^{-1}$ volume above the melting level vs domain-averaged rain rates for rain above $90 \mathrm{~mm} \mathrm{~h}^{-1}$, derived using specific attenuation (Ryzhkov et al. 2014; Giangrande et al. 2014). Domain is blue circle in Fig. 1.

20 May and late on 24 May that consist of many updraft cells at different stages of their life cycles.

As previously mentioned, our results suggest that analysis of $K_{\mathrm{DP}}$ columns above the melting level is useful for characterizing deep convection. Height of $K_{\mathrm{DP}}$ columns, likely related to the life cycle of individual updraft cells, reveal variability that tracks other metrics of storm intensity, in particular on 20 and 24 May where particularly high $K_{\mathrm{DP}}$ columns are observed when lightning flash activity peaks, for example. Nevertheless, further work is planned to better ascertain fundamental spatial characteristics of $K_{\mathrm{DP}}$ columns and other polarimetric features of deep convection and are mentioned in the conclusions. Perhaps unsurprisingly, we find that radar resolution strongly affects measures of $K_{\mathrm{DP}}$ columns. For example, C-SAPR typically detects a greater number of smaller $K_{\mathrm{DP}}$ columns than KVNX. These results are also in agreement with results from Loney et al. (2002), in which radar perception of a $K_{\mathrm{DP}}$ column fails to capture the finescale structure of hydrometeor fields detected in situ.

It should be noted that $Z_{\mathrm{DR}}$ sometimes shows good agreement with lightning as well, such as for the storms on 25 April and 23 May. In particular, $Z_{\mathrm{DR}}$ above the melting level may be better suited to revealing the early appearance of deep convection than $K_{\mathrm{DP}}$ above the melting level. On 25 April and 23 and 24 May, $Z_{\mathrm{DR}}$ volume above the melting level increases to appreciable values (approximately $100 \mathrm{~km}^{2}$ ) $30-60 \mathrm{~min}$ before $K_{\mathrm{DP}}$ volume does. This earlier detection may result from $Z_{\mathrm{DR}}$ column producing convective updrafts that quickly 

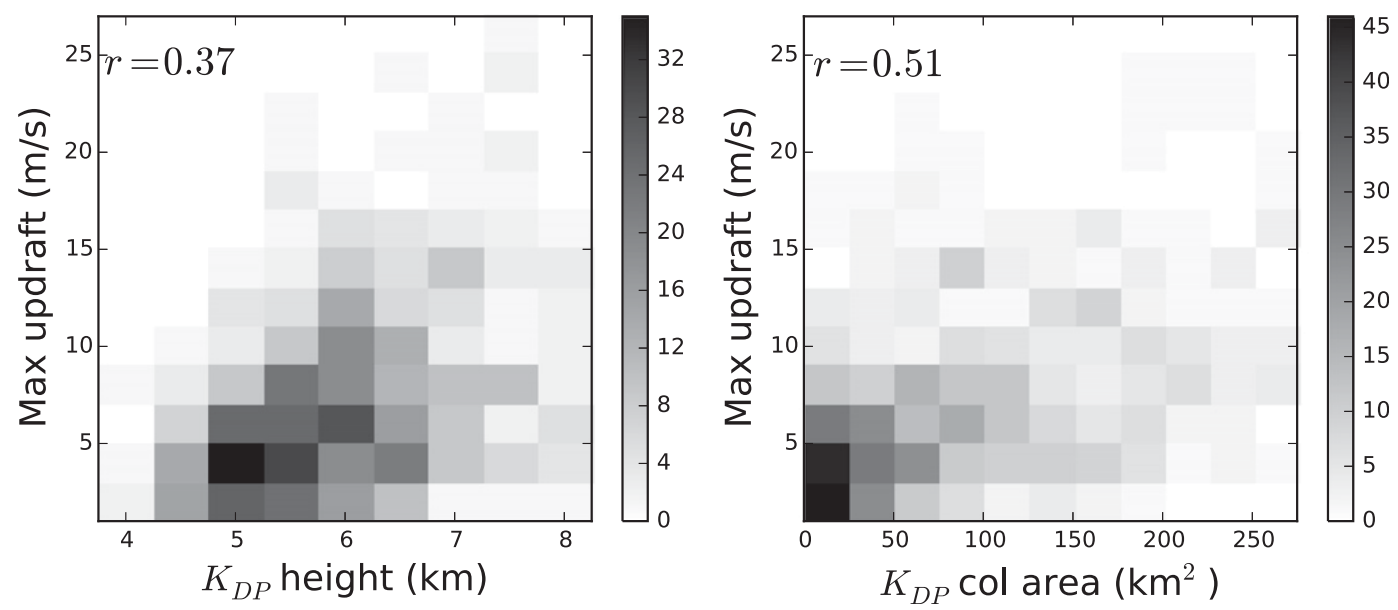

FIG. 12. (left) Joint histogram of $K_{\mathrm{DP}}$ column-top height from the C-SAPR analysis and multi-Doppler-derived maximum updraft speed detected within $K_{\mathrm{DP}}$ column region. (right) Joint histogram of $K_{\mathrm{DP}}$ column area from the C-SAPR analysis and maximum updraft speed. Data aggregated from 25 Apr and 20, 23, and 24 May cases within the domain of the multi-Doppler analysis. Linear correlation coefficients provided within panels.

produce large raindrops in relatively low concentrations through droplet recirculation pathways (Kumjian et al. 2014b). Considerable values of liquid water content that might result in elevated $K_{\mathrm{DP}}$ only occur later as the microphysical processes that produce them become active. These processes may include droplet shedding by wet hail, as suggested by Hubbert et al. (1998), or the formation of mixed-phase hydrometeors (e.g., small wet hail), as suggested by Loney et al. (2002), or lofting of supercooled rain produced by warm-rain processes.

Particularities endemic to the measurement of $Z_{\mathrm{DR}}$ present problems for its use in mapping the life cycle of a
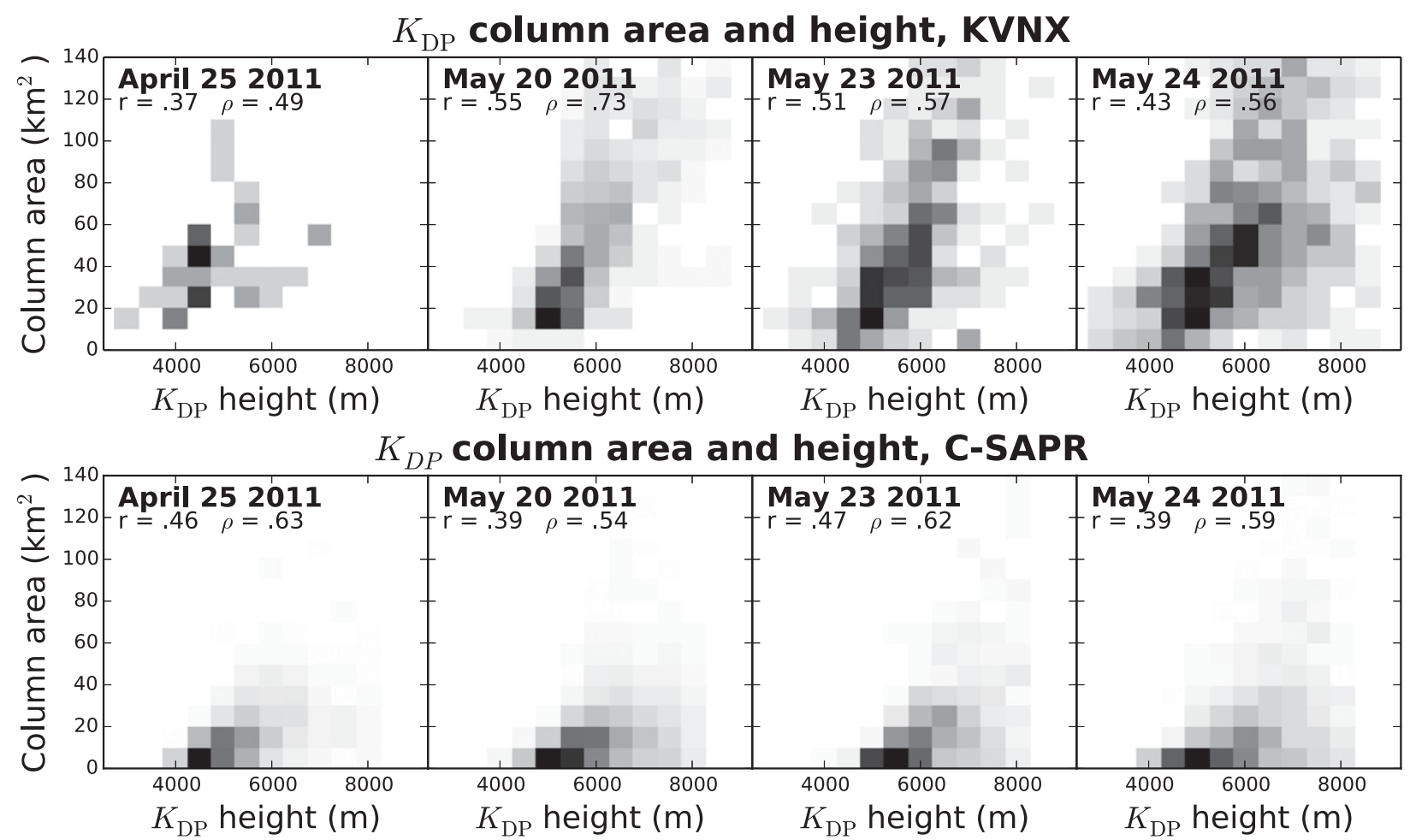

FIG. 13. Comparison of $K_{\mathrm{DP}}>0.75^{\circ} \mathrm{km}^{-1}$ contour heights and $K_{\mathrm{DP}}$ column areas for $K_{\mathrm{DP}}$ columns detected by the (top) KVNX radar and (bottom) C-SAPR radar. Linear $r$ and rank $\rho$ correlation coefficients provided within panels. 


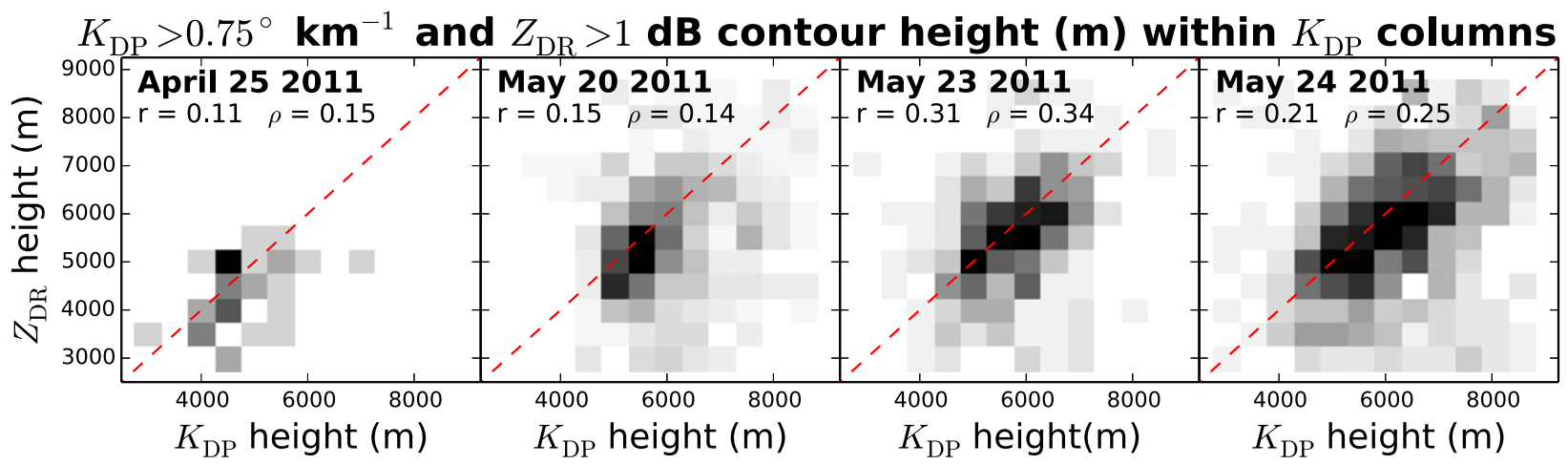

FIG. 14. Comparison of $K_{\mathrm{DP}}>0.75^{\circ} \mathrm{km}^{-1}$ and $Z_{\mathrm{DR}}>1$-dB contour heights for $K_{\mathrm{DP}}$ columns detected from KVNX radar observations. The dotted red line indicates the 1:1 line. Linear correlation coefficients $r$ and rank correlation coefficients $\rho$ are provided within panels.

convection updraft cell. Differential attenuation effects caused by transmission of the radar beam through volumes containing oblate particles may anomalously reduce $Z_{\mathrm{DR}}$, for example between 0900 and $1000 \mathrm{UTC}$ on 20 May, or just after 2000 UTC on 24 May (see Figs. S5 and S9 in the online supplemental material). At other times, the presence of hail as a dominant scatterer may result in small $Z_{\mathrm{DR}}$, despite the continued presence of liquid hydrometeors; it is this feature that is implicated in the "death" of the $Z_{\mathrm{DR}}$ column in
Kumjian et al. (2014b). Finally, degraded resolution causes anomalous values of $Z_{\mathrm{DR}}$ due to nonuniform beam filling when strong spatial gradients of hydrometeors are observed far from the radar Ryzhkov (2007). These effects were only found to be significant on 20 May and are partly responsible for the poor correlation between $Z_{\mathrm{DR}}$ volume and lightning on 20 May shown in Fig. 15. These effects may not be as pronounced for $K_{\mathrm{DP}}$ because they are likely removed during phase processing.

\section{LMA flash density \& KVNX $K_{\mathrm{DP}}$ and $Z_{\mathrm{DR}}$ volumes above melting layer}

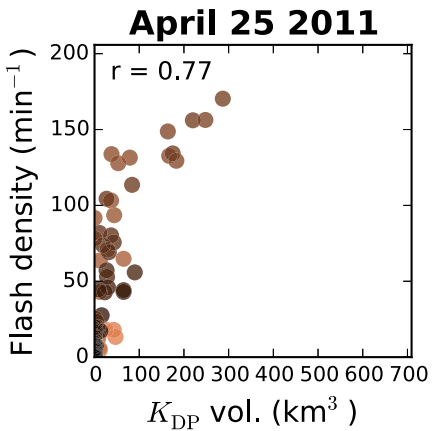

May 202011

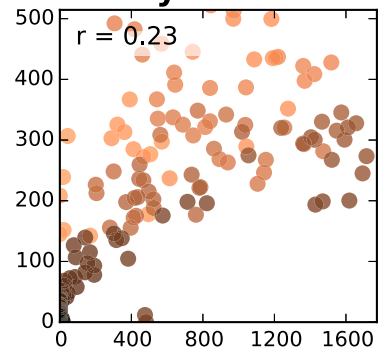

$K_{\mathrm{DP}}$ vol. $\left(\mathrm{km}^{3}\right)$

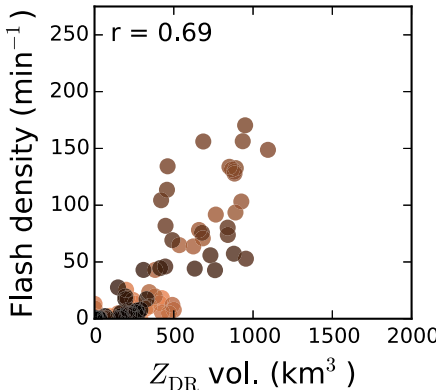

0630 Time (UTC) 1130

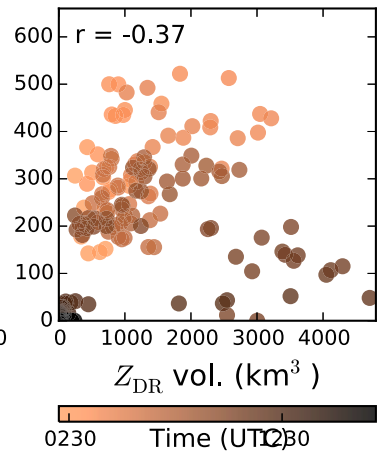

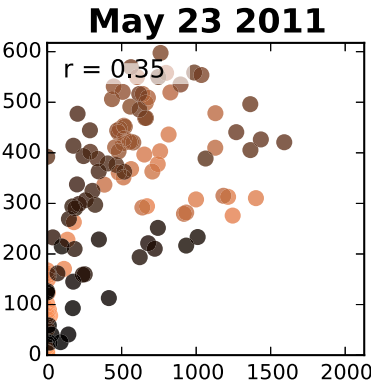

May 242011

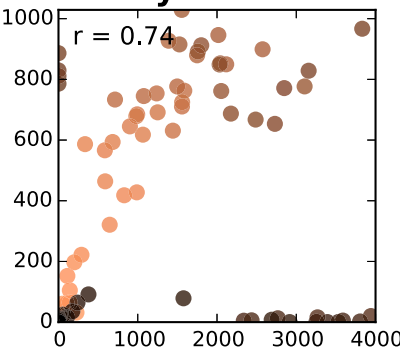

$K_{\mathrm{DP}}$ vol. $\left(\mathrm{km}^{3}\right)$

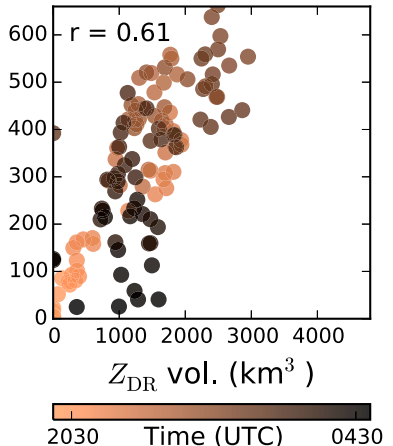

FIG. 15. Comparison of $K_{\mathrm{DP}}>0.75^{\circ} \mathrm{km}^{-1} ; Z_{\mathrm{DR}}>1-\mathrm{dB}$ volumes and total lightning flash rate measured by KVNX and the Oklahoma LMA, respectively, for the 4 days studied here. Points are colored according to relative time during the period of interest. All plots in a given row share a common axis ratio between $x$ and $y$ axes. Linear correlation coefficients are provided in each panel. Data after 2315 UTC 24 May were not included in calculation of correlation owing to possible failure of the LMA at this point. 
Lagged correlations between $K_{\mathrm{DP}}$ and both updraft mass flux and lightning flash rates, observed primarily early on 20 May and throughout 23 May strongly suggest that correlations between $K_{\mathrm{DP}}$ and other aspects of deep convective storm activity occur on the life cycle of an updraft cell rather than the life cycle of a storm system, which may comprise many convective updrafts in various stages of maturity. Stormwide analysis may serve to underestimate these relationships, as multiple updraft cells may be present at differing stages of their life cycles. Cell tracking may allow a more complete characterization of $K_{\mathrm{DP}}$ as a signal of deep convection updrafts. We hypothesize that only by tracking individual updraft cells within larger storm systems can definitive answers be found concerning the variability of $K_{\mathrm{DP}}$ columns within a single storm system as well as between different storm systems. Future work will investigate these ideas, with detailed comparison between modeled and observed updraft cells.

\section{Conclusions}

In this study observations by C- and S-band polarimetric radars of four storm systems during the MC3E field campaign were analyzed to investigate the characteristics of enhanced positive specific differential phase $\left(K_{\mathrm{DP}}\right)$ above the melting level to motivate its use as an observational metric of deep convection updraft properties. The volume above the melting level where $K_{\mathrm{DP}}>0.75^{\circ} \mathrm{km}^{-1}$ and $K_{\mathrm{DP}}>1.5^{\circ} \mathrm{km}^{-1}$ from KVNX and C-SAPR radars, respectively, were recorded. In addition, $K_{\mathrm{DP}}$ columns thought to be proxies for deep convection updraft were identified. These data were then statistically compared with lightning flash activity, $Z_{\mathrm{DR}}$ from KVNX, precipitation estimates from the C-SAPR radar, and updrafts retrieved using two X-band radars and the C-SAPR radar.

The $K_{\mathrm{DP}}$ volume was found to correlate well with retrieved updraft mass flux in three out of four cases, with some evidence that $K_{\mathrm{DP}}$ lags peak updraft mass flux by approximately $14 \mathrm{~min} ; K_{\mathrm{DP}}$ volume also shows a strong relationship with flash rate. Here again there is some indication that lightning flash rates may lag $K_{\mathrm{DP}}$ volume by approximately $10 \mathrm{~min}$. The $K_{\mathrm{DP}}$ column heights were shown to be variable between days studied and also show variability within a single day, in accordance with changes in storm morphology. Despite this, consistent statistical relationships are seen between $K_{\mathrm{DP}}$ column height and column horizontal area. Intense rain rates (above $90 \mathrm{~mm} \mathrm{~h}^{-1}$ ) correlate well with $K_{\mathrm{DP}}$ volume, in contrast to more moderate convective rain rates (above $40 \mathrm{~mm} \mathrm{~h}^{-1}$ ).
This difference indicates that $K_{\mathrm{DP}}$ is best correlated with especially intense convection and may not track moderate deep convection activity as well. Finally, $Z_{\mathrm{DR}}$ volume shows similar correlations as $K_{\mathrm{DP}}$, with $Z_{\mathrm{DR}}$ at times a better indicator of the early stages of deep convection, as well as more moderate convection. Conversely, when convection is more intense, $Z_{\mathrm{DR}}$ may suffer from artifacts related to differential attenuation and other factors. These findings suggest the combined use of $Z_{\mathrm{DR}}$ and $K_{\mathrm{DP}}$ columns to characterize deep convection updrafts.

Loney et al. (2002) note that significant radar resolution degradation may preclude the use of $K_{\mathrm{DP}}$ and $Z_{\mathrm{DR}}$ to ascertain the structure of hydrometeor fields. Comparison between $K_{\mathrm{DP}}$ columns detected by C-SAPR and KVNX further support this result and suggest that NEXRAD radars may be inappropriate for determining fundamental scales of such features because of inadequate range resolution. Work has begun comparing the spatial statistics of polarimetric radar features observed at varying radar resolutions alongside highresolution modeled simulations of deep convection in order to answer questions such as the following: What is the fundamental size of a $K_{\mathrm{DP}}$ or $Z_{\mathrm{DR}}$ column? How closely are these columns spaced from one another? What is the variability of these metrics between and within storm systems? How do characteristics of simulated updrafts and forward-modeled polarimetric properties compare with those observed?

Acknowledgments. This research was supported by the Office of Science (BER), U.S. Department of Energy, Award DE-SC0006988. MC3E data were obtained from the Atmospheric Radiation Measurement (ARM) Program sponsored by the U.S. Department of Energy, Office of Science, Office of Biological and Environmental Research, Climate and Environmental Sciences Division. Argonne National Laboratory's work was supported by the U.S. Department of Energy, Office of Science, Office of Biological and Environmental Research, under Contract DE-AC02-06CH11357. This work has been supported by the Office of Biological and Environmental Research (OBER) of the U.S. Department of Energy (DOE) as part of the ARM Program. The authors thank Scott Giangrande, Alexander Ryzhkov, and Matthew Kumjian for helpful discussions during preparation of this manuscript.

\section{REFERENCES}

Ackerman, T. P., and G. M. Stokes, 2003: The Atmospheric Radiation Measurement Program. Phys. Today, 56, 38-44, doi:10.1063/1.1554135. 
Anderson, N. F., C. A. Grainger, and J. L. Stith, 2005: Characteristics of strong updrafts in precipitation systems over the central tropical Pacific Ocean and in the Amazon. J. Appl. Meteor., 44, 731-738, doi:10.1175/JAM2231.1.

Aydin, K., and V. Giridhar, 1992: C-band dual-polarization radar observables in rain. J. Atmos. Oceanic Technol., 9, 383-390, doi:10.1175/1520-0426(1992)009<0383:CBDPRO > 2.0.CO;2.

, Y. Zhao, and T. A. Seliga, 1989: Rain-induced attenuation effects on C-band dual-polarization meteorological radars. IEEE Trans. Geosci. Remote Sens., 27, 57-66, doi:10.1109/36.20275.

Barnes, S. L., 1964: A technique for maximizing details in numerical weather map analysis. J. Appl. Meteor., 3, 396-409, doi:10.1175/1520-0450(1964)003<0396:ATFMDI>2.0.CO;2.

Biggerstaff, M. I., and R. A. Houze, 1991: Kinematic and precipitation structure of the 10-11 June 1985 squall line. Mon. Wea. Rev., 119, 3034-3065, doi:10.1175/1520-0493(1991)119<3034: KAPSOT $>2.0 . \mathrm{CO} ; 2$.

Blossey, P. N., C. S. Bretherton, J. Cetrone, and M. Kharoutdinov, 2007: Cloud-resolving model simulations of KWAJEX: Model sensitivities and comparisons with satellite and radar observations. J. Atmos. Sci., 64, 1488-1508, doi:10.1175/ JAS3982.1.

Braun, S. A., M. T. Montgomery, K. J. Mallen, and P. D. Reasor, 2010: Simulation and interpretation of the genesis of Tropical Storm Gert (2005) as part of the NASA Tropical Cloud Systems and Processes experiment. J. Atmos. Sci., 67, 999-1025, doi:10.1175/2009JAS3140.1.

Bringi, V. N., and V. Chandrasekar, 2001: Polarimetric Doppler Weather Radar: Principles and Applications. Cambridge University Press, $664 \mathrm{pp}$.

, D. A. Burrows, and S. M. Menon, 1991: Multiparameter radar and aircraft study of raindrop spectral evolution in warmbased clouds. J. Appl. Meteor., 30, 853-880, doi:10.1175/ 1520-0450(1991)030<0853:MRAASO > 2.0.CO;2.

- L. Liu, P. C. Kennedy, V. Chandrasekar, and S. A. Rutledge, 1996: Dual multiparameter radar observations of intense convective storms: The 24 June 1992 case study. Meteor. Atmos. Phys., 59, 3-31, doi:10.1007/BF01031999.

Bruning, E. C., W. D. Rust, T. J. Schuur, D. R. MacGorman, P. R. Krehbiel, and W. Rison, 2007: Electrical and polarimetric radar observations of a multicell storm in TELEX. Mon. Wea. Rev., 135, 2525-2544, doi:10.1175/MWR3421.1.

Calhoun, K. M., D. R. MacGorman, C. L. Ziegler, and M. I. Biggerstaff, 2013: Evolution of lightning activity and storm charge relative to dual-Doppler analysis of a high-precipitation supercell storm. Mon. Wea. Rev., 141, 2199-2223, doi:10.1175/ MWR-D-12-00258.1.

Caniaux, G., J.-P. Lafore, and J.-L. Redelsperger, 1995: A numerical study of the stratiform region of a fast-moving squall line. Part II: Relationship between mass, pressure, and momentum fields. J. Atmos. Sci., 52, 331-352, doi:10.1175/ 1520-0469(1995)052<0331:ANSOTS >2.0.CO;2.

Carey, L. D., and S. A. Rutledge, 1998: Electrical and multiparameter radar observations of a severe hailstorm. J. Geophys. Res., 103, 13 979-14 000, doi:10.1029/97JD02626.

$\longrightarrow,-$ D. A. Ahijevych, and T. D. Keenan, 2000: Correcting propagation effects in C-band polarimetric radar observations of tropical convection using differential propagation phase. J. Appl. Meteor., 39, 1405-1433, doi:10.1175/ 1520-0450(2000)039<1405:CPEICB > 2.0.CO;2.

Cifelli, R., and V. Chandrasekar, 2010: Dual-polarization radar rainfall estimation. Rainfall: State of the Science, F. Y. Testik and M. Gebremichael, Eds., Amer. Geophys. Union, 105-125.
Collis, S., A. Protat, and K.-S. Chung, 2010: The effect of radial velocity gridding artifacts on variationally retrieved vertical velocities. J. Atmos. Oceanic Technol., 27, 1239-1246, doi:10.1175/ 2010JTECHA1402.1.

, — - P. T. May, and C. Williams, 2013: Statistics of storm updraft velocities from TWP-ICE including verification with profiling measurements. J. Appl. Meteor. Climatol., 52, 19091922, doi:10.1175/JAMC-D-12-0230.1.

Deierling, W., and W. A. Petersen, 2008: Total lightning activity as an indicator of updraft characteristics. J. Geophys. Res., 113, D16210, doi:10.1029/2007JD009598.

Doviak, R. J., and D. S. Zrnić, 1993: Doppler Radar and Weather Observations. Courier Dover Publications, 562 pp.

Fridlind, A. M., and Coauthors, 2012: A comparison of TWP-ICE observational data with cloud-resolving model results. J. Geophys. Res., 117, D05204, doi:10.1029/2011JD016595.

Giangrande, S. E., R. McGraw, and L. Lei, 2013: An application of linear programming to polarimetric radar differential phase processing. J. Atmos. Oceanic Technol., 30, 1716-1729, doi:10.1175/JTECH-D-12-00147.1.

— S. Collis, A. K. Theisen, and A. Tokay, 2014: Precipitation estimation from the ARM distributed radar network during the MC3E campaign. J. Appl. Meteor. Climatol., 53, 21302147, doi:10.1175/JAMC-D-13-0321.1.

Gray, M. E. B., 2000: Characteristics of numerically simulated mesoscale convective systems and their application to parameterization. J. Atmos. Sci., 57, 3953-3970, doi:10.1175/ 1520-0469(2001)058<3953:CONSMC $>2.0$. CO;2.

Griffin, E. M., T. J. Schuur, D. R. MacGorman, M. R. Kumjian, and A. O. Fierro, 2014: An electrical and polarimetric analysis of the overland reintensification of Tropical Storm Erin (2007). Mon. Wea. Rev., 142, 2321-2344, doi:10.1175/ MWR-D-13-00360.1.

Heistermann, M., and Coauthors, 2015: The emergence of opensource software for the weather radar community. Bull. Amer. Meteor. Soc., 96, 117-128, doi:10.1175/BAMS-D-13-00240.1.

Heymsfield, A. J., A. Bansemer, P. R. Field, S. L. Durden, J. L. Stith, J. E. Dye, W. Hall, and C. A. Grainger, 2002: Observations and parameterizations of particle size distributions in deep tropical cirrus and stratiform precipitating clouds: Results from in situ observations in TRMM field campaigns. J. Atmos. Sci., 59, 3457-3491, doi:10.1175/ 1520-0469(2002)059<3457:OAPOPS > 2.0.CO;2.

Homeyer, C. R., and M. R. Kumjian, 2015: Microphysical characteristics of overshooting convection from polarimetric radar observations. J. Atmos. Sci., 72, 870-891, doi:10.1175/ JAS-D-13-0388.1.

Hubbert, J., V. N. Bringi, L. D. Carey, and S. Bolan, 1998: CSUCHILL polarimetric radar measurements from a severe hail storm in eastern Colorado. J. Appl. Meteor., 37, 749-775, doi:10.1175/1520-0450(1998)037<0749:CCPRMF>2.0.CO;2.

_ S. M. Ellis, W.-Y. Chang, and Y.-C. Liou, 2014: X-band polarimetric observations of cross coupling in the ice phase of convective storms in Taiwan. J. Appl. Meteor. Climatol., 53, 1678-1695, doi:10.1175/JAMC-D-13-0360.1.

Jayaratne, E., C. Saunders, and J. Hallett, 1983: Laboratory studies of the charging of soft-hail during ice crystal interactions. Quart. J. Roy. Meteor. Soc., 109, 609-630, doi:10.1002/ qj. 49710946111.

Kumjian, M. R., 2013: Principles and applications of dualpolarization weather radar. Part I: Description of the polarimetric radar variables. J. Oper. Meteor., 1, 226-242, doi:10.15191/ nwajom.2013.0119. 
— , and A. V. Ryzhkov, 2009: Storm-relative helicity revealed from polarimetric radar measurements. J. Atmos. Sci., 66, 667685, doi:10.1175/2008JAS2815.1.

- A. P. Khain, N. Benmoshe, E. Ilotoviz, A. V. Ryzhkov, and V. T. J. Phillips, 2014a: The anatomy and physics of $z_{D R}$ columns: Investigating a polarimetric radar signature with a spectral bin microphysics model. J. Appl. Meteor. Climatol., 53, 1820-1843, doi:10.1175/JAMC-D-13-0354.1.

—, S. A. Rutledge, R. M. Rasmussen, P. C. Kennedy, and M. Dixon, 2014b: High-resolution polarimetric radar observations of snow-generating cells. J. Appl. Meteor. Climatol., 53, 1636-1658, doi:10.1175/JAMC-D-13-0312.1.

Lang, S., W.-K. Tao, J. Simpson, and B. Ferrier, 2003: Modeling of convective-stratiform precipitation processes: Sensitivity to partitioning methods. J. Appl. Meteor., 42, 505-527, doi:10.1175/1520-0450(2003)042<0505:MOCSPP>2.0.CO;2.

,,-- X. Zeng, and Y. Li, 2011: Reducing the biases in simulated radar reflectivities from a bulk microphysics scheme: Tropical convective systems. J. Atmos. Sci., 68, 2306-2320, doi:10.1175/JAS-D-10-05000.1.

Lang, T. J., and S. A. Rutledge, 2002: Relationships between convective storm kinematics, precipitation, and lightning. Mon. Wea. Rev., 130, 2492-2506, doi:10.1175/1520-0493(2002)130<2492: $\mathrm{RBCSKP}>2.0 . \mathrm{CO} ; 2$.

Lawson, R. P., E. Jensen, D. L. Mitchell, B. Baker, Q. Mo, and B. Pilson, 2010: Microphysical and radiative properties of tropical clouds investigated in TC4 and NAMMA. J. Geophys. Res., 115, D00J08, doi:10.1029/2009JD013017.

Levin, Z., and W. R. Cotton, Eds., 2008: Aerosol Pollution Impact on Precipitation: A Scientific Review. Springer, 386 pp.

Loney, M. L., D. S. Zrnić, J. M. Straka, and A. V. Ryzhkov, 2002: Enhanced polarimetric radar signatures above the melting level in a supercell storm. J. Appl. Meteor., 41, 1179-1194, doi:10.1175/1520-0450(2002)041<1179:EPRSAT>2.0.CO;2.

Lund, N. R., D. R. MacGorman, T. J. Schuur, M. I. Biggerstaff, and W. D. Rust, 2009: Relationships between lightning location and polarimetric radar signatures in a small mesoscale convective system. Mon. Wea. Rev., 137, 4151-4170, doi:10.1175/ 2009MWR2860.1.

MacGorman, D. R., and Coauthors, 2008: TELEX: The Thunderstorm Electrification and Lightning Experiment. Bull. Amer. Meteor. Soc., 89, 997-1013, doi:10.1175/ 2007BAMS2352.1.

Mather, J. H., and J. W. Voyles, 2013: The ARM Climate Research Facility: A review of structure and capabilities. Bull. Amer. Meteor. Soc., 94, 377-392, doi:10.1175/BAMS-D-11-00218.1.

Matsui, T., X. Zeng, W.-K. Tao, H. Masunaga, W. S. Olson, and S. Lang, 2009: Evaluation of long-term cloud-resolving model simulations using satellite radiance observations and multifrequency satellite simulators. J. Atmos. Oceanic Technol., 26, 1261-1274, doi:10.1175/2008JTECHA1168.1.

_ , W.-K. Tao, S. J. Munchak, M. Grecu, and G. J. Huffman, 2015: Satellite view of quasi-equilibrium states in tropical convection and precipitation microphysics. Geophys. Res. Lett., 42, 1959-1968, doi:10.1002/2015GL063261.

Mechem, D. B., S. S. Chen, and R. A. Houze, 2006: Momentum transport processes in the stratiform regions of mesoscale convective systems over the western Pacific warm pool. Quart. J. Roy. Meteor. Soc., 132, 709-736, doi:10.1256/qj.04.141.

Mrowiec, A. A., O. M. Pauluis, A. M. Fridlind, and A. S. Ackerman, 2015: Properties of a mesoscale convective system in the context of an isentropic analysis. J. Atmos. Sci., 72, 1945-1962, doi:10.1175/JAS-D-14-0139.1.
North, K. W., 2016: Kinematic retrievals in deep convective clouds from a network of scanning Doppler radars in Oklahoma during MC3E. M.S. thesis, McGill University, Montreal, Quebec, Canada.

Parker, M. D., and R. H. Johnson, 2000: Organizational modes of midlatitude mesoscale convective systems. Mon. Wea. Rev., 128, 3413-3436, doi:10.1175/1520-0493(2001)129<3413: $\mathrm{OMOMMC}>2.0 . \mathrm{CO} ; 2$.

Payne, C. D., T. J. Schuur, D. R. MacGorman, M. I. Biggerstaff, K. M. Kuhlman, and W. D. Rust, 2010: Polarimetric and electrical characteristics of a lightning ring in a supercell storm. Mon. Wea. Rev., 138, 2405-2425, doi:10.1175/ 2009MWR3210.1.

Pereyra, R. G., E. E. Avila, N. E. Castellano, and C. P. Saunders, 2000: A laboratory study of graupel charging. J. Geophys. Res., 105, 20 803-20 812, doi:10.1029/2000JD900244.

Reynolds, S., M. Brook, and M. F. Gourley, 1957: Thunderstorm charge separation. J. Meteor., 14, 426-436, doi:10.1175/ 1520-0469(1957)014<0426:TCS >2.0.CO;2.

Roerdink, J. B. T. M., and A. Meijster, 2001: The watershed transform: Definitions, algorithms and parallelization strategies. Fundamenta Informaticae, 41, 187-228.

Ryzhkov, A. V., 2007: The impact of beam broadening on the quality of radar polarimetric data. J. Atmos. Oceanic Technol., 24, 729-744, doi:10.1175/JTECH2003.1.

_- and D. S. Zrnić, 1996: Assessment of rainfall measurement that uses specific differential phase. J. Appl. Meteor., 35, 2080-2090, doi:10.1175/1520-0450(1996)035<2080: AORMTU $>2.0 . \mathrm{CO} ; 2$.

, M. Diederich, P. Zhang, and C. Simmer, 2014: Potential utilization of specific attenuation for rainfall estimation, mitigation of partial beam blockage, and radar networking. J. Atmos. Oceanic Technol., 31, 599-619, doi:10.1175/ JTECH-D-13-00038.1.

Sachidananda, M., and D. S. Zrnić, 1986: Differential propagation phase shift and rainfall rate estimation. Radio Sci., 21, 235247, doi:10.1029/RS021i002p00235.

Shi, J. J., and Coauthors, 2010: WRF simulations of the 2022 January 2007 snow events over eastern Canada: Comparison with in situ and satellite observations. J. Appl. Meteor. Climatol., 49, 2246-2266, doi:10.1175/2010JAMC2282.1.

Steiner, M., and J. A. Smith, 1998: Convective versus stratiform rainfall: An ice-microphysical and kinematic conceptual model. Atmos. Res., 47-48, 317-326, doi:10.1016/S0169-8095(97)00086-0.

Stith, J. L., J. E. Dye, A. Bansemer, A. J. Heymsfield, C. A. Grainger, W. A. Petersen, and R. Cifelli, 2002: Microphysical observations of tropical clouds. J. Appl. Meteor., 41, 97-117, doi:10.1175/ 1520-0450(2002)041<0097:MOOTC >2.0.CO;2.

- J. A. Haggerty, A. Heymsfield, and C. A. Grainger, 2004: Microphysical characteristics of tropical updrafts in clean conditions. J. Appl. Meteor., 43, 779-794, doi:10.1175/2104.1.

,-- C. Grainger, and A. Detwiler, 2006: A comparison of the microphysical and kinematic characteristics of mid-latitude and tropical convective updrafts and downdrafts. Atmos. Res., 82 (1-2), 350-366, doi:10.1016/j.atmosres.2005.12.008.

Takahashi, T., 1978: Riming electrification as a charge generation mechanism in thunderstorms. J. Atmos. Sci., 35, 1536-1548, doi:10.1175/1520-0469(1978)035<1536:REAACG > 2.0.CO;2.

Tao, W.-K., J.-P. Chen, Z. Li, C. Wang, and C. Zhang, 2012: Impact of aerosols on convective clouds and precipitation. Rev. Geophys., 50, RG2001, doi:10.1029/2011RG000369.

, and Coauthors, 2014: The Goddard Cumulus Ensemble model (GCE): Improvements and applications for studying 
precipitation processes. Atmos. Res., 143, 392-424, doi:10.1016/ j.atmosres.2014.03.005.

Tessendorf, S. A., L. J. Miller, K. C. Wiens, and S. A. Rutledge, 2005: The 29 June 2000 supercell observed during STEPS. Part I: Kinematics and microphysics. J. Atmos. Sci., 62, 4127-4150, doi:10.1175/JAS3585.1.

, S. A. Rutledge, and K. C. Wiens, 2007a: Radar and lighting observations of normal and inverted polarity multicellular storms from steps. Mon. Wea. Rev., 135, 3682-3706, doi:10.1175/2007MWR1954.1.

_ K. C. Wiens, and S. A. Rutledge, 2007b: Radar and lighting observations of the 3 June 2000 electrically inverted storm from STEPS. Mon. Wea. Rev., 135, 3665-3681, doi:10.1175/ 2006MWR1953.1.

Thomas, R. J., P. R. Krehbiel, W. Rison, S. J. Hunyady, W. P. Winn, T. Hamlin, and J. Harlin, 2004: Accuracy of the lightning mapping array. J. Geophys. Res., 109, D14207, doi:10.1029/2004JD004549.

Trapp, R. J., and C. A. Doswell III, 2000: Radar data objective analysis. J. Atmos. Oceanic Technol., 17, 105-120, doi:10.1175/ 1520-0426(2000)017<0105:RDOA > 2.0.CO;2.

Varble, A., and Coauthors, 2011: Evaluation of cloud-resolving model intercomparison simulations using TWP-ICE observations: Precipitation and cloud structure. J. Geophys. Res., 116, D12206, doi:10.1029/2010JD015180.
— , and Coauthors, 2014a: Evaluation of cloud-resolving and limited area model intercomparison simulations using TWPICE observations: 1. Deep convective updraft properties. J. Geophys. Res. Atmos., 119, 13 891-13918, doi:10.1002/ 2013JD021371

—_ and Coauthors, 2014b: Evaluation of cloud-resolving and limited area model intercomparison simulations using TWP-ICE observations: 2. Precipitation microphysics. J. Geophys. Res. Atmos., 119, 13 919-13 945, doi:10.1002/ 2013JD021372.

Wiens, K. C., S. A. Rutledge, and S. A. Tessendorf, 2005: The 29 June 2000 supercell observed during STEPS. Part II: Lightning and charge structure. J. Atmos. Sci., 62, 4151-4177, doi:10.1175/JAS3615.1.

Zeng, X., W.-K. Tao, S. W. Powell, R. A. Houze, P. Ciesielski, N. Guy, H. Pierce, and T. Matsui, 2013: A comparison of the water budgets between clouds from AMMA and TWP-ICE. J. Atmos. Sci., 70, 487-503, doi:10.1175/JAS-D-12-050.1.

Zhu, P., and Coauthors, 2012: A limited area model (LAM) intercomparison study of a TWP-ICE active monsoon mesoscale convective event. J. Geophys. Res., 117, D11208, doi:10.1029/2011JD016447.

Zrnić, D. S., and A. V. Ryzhkov, 1999: Polarimetry for weather surveillance radars. Bull. Amer. Meteor. Soc., 80, 389-406, doi:10.1175/1520-0477(1999)080<0389:PFWSR >2.0.CO;2. 